\title{
To an Alien Mecca: Durban Port and its WATERFRONTS BEFORE 1914
}

\author{
Andrew MacDonald \\ University of the Witwatersrand
}

\begin{abstract}
Between 1860 and 1914, three to four million people passed along Durban's waterfronts, most travelling to or from an industrialising hinterland that a colonial gatekeeper called a 'Mecca for aliens.' This article explores mass migration through Durban and the changes the phenomenon brought to the social world and built environments around the lagoon that forms today's large container port. Using Immigration, Harbour Department and Water Police archives, it shows how the lagoon, until the mid-nineteenth century an obscure outlier in the Indian Ocean World, became deeply integrated with processes simultaneously underway across much of maritime Asia. After an introduction that places colonial Durban alongside the wider changes common to many Indian-Ocean ports, we set the scene with an overview of the lagoon's deep precolonial past. The core argument then moves through several phases. First, economic and technological developments from the 1850 s, designed to inflate cargo capacity, also intensified transoceanic migrant traffic. This generated a rich cultural heterogeneity on the lagoon's fringes. Second, mass migration fueled a backlash among colonial authorities, who built an elaborate architecture of detention and surveillance around the inner shore. Third, some migrants subverted the new order by 'jumping ship' in creative ways, ensuring the waterfronts remained, for a time, unruly heterotopia. In these ways, Durban became a characteristic Indian Ocean port city. But Durban authorities introduced an unusual element: to the north they created a recreational beachfront for settler elites. This ultimately reorientated the city's waterfront away from the lagoon to the open ocean, casting the former's social history into the shadows.
\end{abstract}

(C) Andrew MacDonald. This is an Open Access article distributed under the terms of the Creative Commons License CC BY NC SA, which permits users to share, use, and remix the material provided they give proper attribution, the use is noncommercial, and any remixes/transformations of the work are shared under the same license as the original. 
In 2003, on a finger of land close to the entrance to Durban lagoon, an archaeologist uncovered a skeleton of a young adult, about twenty. ${ }^{1}$ The burial took place between 1880 and 1920 at the Point, in a cluster of rough dwellings separated from ocean spray by warehouses (see appended maps). Wrapped in a black hessian shawl and feet pointing east, the skeleton wore a skirt embroidered with oyster buttons, a brass buckle and the cuffs of a British soldier's jacket. Around the skull fell seashell earrings, on the chest a mother-of-pearl brooch. Nearby lay the detritus of a busy thoroughfare: amid bottles, shoes and sardine tins, there lay imported dice, tobacco pipes and a crude gold ring. In addition, there was a stray Portuguese coin, a lice-comb, and cattle bones. Much else reminds us that the Point was a gateway into (and out of) an industrialising hinterland, which a turn of the century gatekeeper called 'a Mecca for Aliens.' ${ }^{2}$ We can say little more about the deceased's biography or cause of death; the remains are in museum storage, and property developers have tarred the excavation site with an aquarium car park.

The skeleton in the black shawl draws our attention to Durban port and its global entanglements, the subject of this article. Although Durban's docklands received only partial attention in a recent special issue on South Africa's maritime edges, the city is well-researched. ${ }^{3}$ Scholars have richly charted the city's role in creating a sub-continental racial order, and resistance to it. ${ }^{4}$ The harbour itself has an old tradition of economic and technical histories, ${ }^{5}$ and a well-established labour historiography that explains internal peasant migrations to the port and their gradual, uneven transformation into wellorganised industrial dockworkers; two important interventions consider dockside labour

\footnotetext{
${ }^{1}$ Gavin Anderson, uShaka Island Marine Park, Point, Durban: Survey of the development area and excavations of Bamboo Square (Pietermaritzburg: Natal Museum, 2004), 17-18.

${ }^{2}$ Natal Archives Bureau, Pietermaritzburg (hereafter NAB), Annual Report of the Immigration Restriction Department (hereafter ARIRD) for 1902 (Pietermaritzburg: Government Printer, 1903), 8.

${ }^{3}$ See: Isabel Hofmeyr, Uma Dhupelia-Mesthrie and PrebenKaarsholm (eds.), "Durban and Cape Town as Port Cities:

Reconsidering southern African studies from the Indian Ocean," Journal of Southern African Studies (Special Issue), 42, 3, (2016).

${ }^{4}$ Milestones are: Maynard W. Swanson, “'The Asiatic menace': Creating segregation in Durban, 1870-1900,” International Journal of African Historical Studies 16, 3 (1983), 401-21, Paul Maylam and Iain Edwards (eds.), The People's City: African life in twentieth century Durban (Pietermaritzburg: University of Natal Press, 1996); Vivian Bickford-Smith, The Emergence of the South African Metropolis: Cities and identities in the twentieth century (Cambridge: Cambridge University Press, 2016).

${ }^{5}$ J. Forsyth Ingram, The Story of an African Seaport (Durban: G. Coester, 1899); Bill Guest and John Sellers (eds.), Enterprise and Exploitation in a Victorian Colony: Aspects of the economic and social history of colonial Natal (Pietermaritzburg: University of Natal Press, 1985); A.B. Lumby, "The South African economy and the development of the port of Durban during the inter-war years," The Great Circle, 13, 1 (1991), 21-34; A.B. Lumby, "The development of the port of Durban during the 'long Capitalist boom'," The Great Circle, 14, 2 (1992), 105-13; Colin Bender, Who Saved Natal? The Victorian harbour engineers of colonial Port Natal (Durban: C.C. Bender, 1988); Tony Pearson, African Keyport: Story of the port of Durban (Durban: Accucut Books, 1995); Brian Kearney, Alas Poor Little Colony: An illustrated history of Port Natal. Vols 1-3 (Durban: Durban Heritage Trust, 2013).
} 
politics from the perspective of maritime labourers. ${ }^{6}$ For most migration histories, the harbour naturally forms a backdrop, though it is rarely central. ${ }^{7}$ The most recent work, meanwhile, has turned toward the charged passage of counter-colonial ideas and illicit things. ${ }^{8}$ This article builds on this work but turns the focus, like Hofmeyr, explicitly to the city's terraqueous zones - those liminal, littoral spaces, neither sea nor soil, where water and land make incessant claims upon one another. ${ }^{9}$ Taking space - in this case a lagoon and the built environments that developed on and immediately around it - rather than race, class or capital as the organising frame opens the possibility for a history of the port that is at once more diachronic, less bound by ethnic particularism, and more outwardly orientated.

This article explores how Durban lagoon became part of the Indian Ocean World. The lagoon was a far outlier in preindustrial times, as we explore in the first section. Although populated through unusually deep spans of time, until the nineteenth century it had no significant hinterland polities nor littoral exporters or consumers for which it might become a conduit, as at proximate Chibuene, Kilwa or, further afield, classical Berenice, Dilmun or Barygaza, or later Canton, Quanzhou or Ayutthaya (to pick a few cardinal entrepots of the premodern Indian Ocean). ${ }^{10}$ Nor did the lagoon's oceanic location give it any strategic advantage. Despite evidence of transoceanic exchange commodities around Durban's Iron Age/ 'medieval' lagoon, it was neither a hinge between oceanic trading segments, nor between climatic or hydrological zones, and it did not enjoy any hintersea - say an archipelago or enclosed gulf - as in old Cochin, Hormuz, Socotra or Malacca.

\footnotetext{
${ }^{6}$ David Hemson, "Class consciousness and migrant workers : Dock workers of Durban” (Unpublished PhD diss.: University of Warwick, 1979); Bernard Dubbeld, "Breaking the buffalo: The transformation of stevedoring work in Durban between 1970 and 1990," International Review of Social History, 48, 11 (2003), 97-122; Jonathan Hyslop, "Oceanic mobility and settler-colonial power: Policing the global maritime labour force in Durban harbour c.1890-1910," Journal of Transport History, 36, 2 (2015), 248-67; Jonathan Hyslop, "The politics of disembarkation: Empire, shipping and labor in the port of Durban, 1897-1947," International Labor and Working-Class History, 93 (2018), 176-200; Ralph Callebert, On Durban's Docks: Zulu workers, rural households, global labour (Rochester, NY: University of Rochester Press, 2018); Peter Cole, Dockworker Power: Race and activism in Durban and San Francisco (Chicago: University of Illinois Press, 2018).

${ }^{7}$ Best developed with respect to South Asians, most recently in: Ashwin Desai and Goolam Vahed, Inside Indenture: A South African story, 1860-1914 (Durban: Madiba, 2008); Goolam Vahed and Surendra Bhana, Crossing Space and Time across the Indian Ocean: Early Indian traders in Natal, a biographical study (Pretoria: Unisa, 2012).

${ }^{8}$ Shamil Jeppie, Language, Identity, Modernity: The Arabic study circle of Durban (Pretoria; Human Sciences Research Council, 2007); Mark R. Frost, "In search of cosmopolitan discourse: A historical journey across the Indian Ocean from Singapore to South Africa, 1870-1920," in Eyes Across the Water: Navigating the Indian Ocean, eds. Pamila Gupta, Isabel Hofmeyr, and Michael Pearson (Pretoria: Unisa, 2010), 75-95; Isabel Hofmeyr, Dockside Reading: Hydrocolonialism and the customs house (Durham, NC: Duke University Press, 2021).

${ }^{9}$ For a productive resurrection of this seventeenth-century term, see: Alison Bashford, "Terraqueous Histories," Historical Journal, 60, 2 (2017), 253-72.

${ }^{10}$ For the widest comparative treatment, see: David Abulafia, The Boundless Sea: A human history of the oceans (Oxford: Oxford Univ. Press, 2019), 85-272.
} 
Between the sixteenth and early nineteenth centuries, Europeans encountered the lagoon in only the smallest numbers and lived in threadbare, creolised encampments, not the bridgehead forts and factories that characterised Sofala, Mozambique Island, Goa, Madras, Batavia, Penang and many others. ${ }^{11}$ Even when large, centralised and aristocratic interior sates appeared in Southeast Africa between the 1790s and 1820s - a change driven largely by ecological pressures and culminating with the establishment of the Zulu, Pedi, Gazan and Swazi and Tonga polities - long-distance exchange (primarily African ivory, cattle and some slaves for European and Asian beads, brass and textiles) was limited, orientated largely toward Delagoa Bay and Inhambane, several hundred kilometres north. ${ }^{12}$ Where the lagoon presented something like a waterfront, it was open, contingent and uncertain.

As we will see in the second section, from the mid-nineteenth century, an alliance of merchants and administrators stimulated an import-export market. While southern Africa turned inward, Durban evolved affinities with, and in many instances came to resemble, costal nodes elsewhere in maritime Asia. Sometimes this occurred through parallel developments and sometimes through more direct integration and interconnection, the 'interconnected synchronicity' that Hazareesingh's has productively explored of Bombay. ${ }^{13}$ This reminds us, as Sugata Bose, Thomas Metcalf and others have argued (without a close focus on Durban), that horizontal relationships between 'subimperial' regions were as significant as those between colonial peripheries and metropolitan cores. ${ }^{14}$

Studying newly uncovered Immigration, Water Police and Harbour Board records, this article traces how Durban paralleled, if not converged with, Indian Ocean ports in several ways. As shipping traffic, driven by both new steamships and still flourishing sailing vessels, intensified across the Indian Ocean after the opening of the Suez Canal in 1869 , both the volume of vessels and the diversity of ports of origin visiting Durban increased exponentially. Over the same decades, Durban's lagoon mirrored many diverse Indian Ocean ports, both in its environmental challenges and in a mania for marine

\footnotetext{
${ }^{11}$ Ibid., 594-610.

${ }^{12}$ For the most recent treatment, see: Linell Chewins, "Trading societies and their networks in Southeast Africa: Social and political change on the coasts and interiors of Inhambane and Delagoa Bay, 1729-1823" (Unpublished PhD diss., University of the Witwatersrand, 2020).

${ }^{13}$ Sandip Hazareesingh, "Interconnected synchronicities: The production of Bombay and Glasgow as modern global ports c.1850-1880," Journal of Global History, 4, 1 (2009), 7-31.

${ }^{14}$ Sugata Bose, A Hundred Horizons: The Indian Ocean in the Age of Global Empire (Cambridge, MA: Harvard Univerity Press, 2006); Thomas Metcalf, Imperial Networks: India in the Indian Ocean arena (Berkeley: University of California Press, 2008).
} 
excavation. As will we see, Durban engineers developed breakwaters, wharves, piers, and dredging systems, and they reclaimed swampy land for wharfs and esplanades in stages between 1855 and 1910. This developed in step, and often in dialogue, with closely related hydro-projects in diverse parts of the Indian Ocean (and its Red Sea and South China Sea extensions), as port developers rivalled one another to attract the cargo trade. ${ }^{15}$ Besides Suez itself and southern African ports of Cape Town and Algoa, in the Anglophone world the most conspicuous and earliest were in the Hong Kong-Kowloon marine amphitheatre (initially a haphazard quayside development made systematic between 1855-69, and again from 1884), the great breakwaters at exposed Madras (works in 1859-60, 1877-95 and from 1906), and the Manora breakwater at Karachi, whose near-enclosed lagoon and sandbars bore striking parallels to Durban (1867-74). Even in different port environments, being either older or riverine, reconstruction proceeded in ways colonial Durbanites recognised. ${ }^{16}$ In almost all the ports, autonomous public associations - usually called Trusts, Boards or Commissions - formed to raise finance, centralise complex planning, and enclose watersides for capital investment and colonial property ownership regimes. Durban's Harbour Board, established 1880, was a prime example of these new institutions that structured so much of the ocean's exchanges.

Parallels between Durban and other Indian Ocean ports went beyond the technocratic and legal, as becomes clear in sections 3 and 4. Recent migration scholarship points to the Indian Ocean as a dynamic arena of transoceanic voyaging. McKeown estimated over forty million voyagers, free and unfree, between the 1840s and 1940s, which matched and, in some respects, eclipsed migration in the Atlantic world. ${ }^{17}$ Indian Ocean migration ensured Durban's population boomed approximately thirteen-fold from about five thousand to sixty-five thousand - between 1860 and 1910. But even this

\footnotetext{
${ }^{15}$ For an overview, see: Frank Broeze, Peter Reeves, and Kenneth McPherson, "Imperial ports and the modern world economy: The case of the Indian Ocean," in Port and Harbour Engineering, $2^{\text {nd }}$ ed., ed. Adrian Jarvis (London: Routledge, 2016), unpaginated. The South China Sea and the Red Sea, not considered in the above, can be followed in, respectively: Collette Dubois, "The Red Sea ports during the revolution in transportation,1800-1914," in Modernity and Culture: From the Mediterranean to the Indian Ocean, eds. Leila Tawazi Faraz and C.A Bayly (New York: Columbia University Press, 2002), 58-74; Stephen Davies, “Terminal dilemma: Hong Kong's waterfront, 1841-1891," Australian Journal of Victorian Studies, 20, 1 (2015), 5-23.

${ }^{16}$ Consider harbour work in Bombay/Mazgaon (1870-1904), Singapore (1878-1917), Calcutta/Kidderpore (commenced 1889), Freemantle (1893-1903) and Sheikh Barhut/Port Sudan (1899-1909). Elsewhere, similar developments occurred in Egyptian Massawa and Berber on the Red Sea (1875-82), Dutch Batavia/Tanjung Priok (from 1877, expanded 1910-16), Belawan and Sabang (both from the mid-1890s), as well as in Francophone Saigon/Khánh Hội (1881, extended 1903-1912) and Djibouti (from 1892), and further still in Lusophone Delagoa Bay/Lourenço Marques (1900-1905). Even this list is not comprehensive, leaving off several ports that were the subject of pre-War study but for which construction did not fully begin until after 1918: Cochin, Zanzibar, Basra, Port Louis, Tamatave, Beira and Mombasa, among others.

${ }^{17}$ Adam McKeown, “Global migration, 1846-1940,” Journal of World History, 15, 2 (2004), 155-89.
} 
does not account for the perhaps 3-4 million transient visitors, a figure we unpack below, who passed through the port in the same period. This enormous number, the totality invisible in extant accounts of the city, allows us to place Durban alongside much more conspicuous migration and demographic growth nodes around the Indian Ocean rim (with Durban's high proportion of inward migration setting it apart from some).

Further, new scholarship holds that Indian Ocean mobility, free and unfree, led to the growth of urban environments characterised by distinctive concentrations of ethnic, linguistic heterogeneity and 'simultaneity.' ${ }^{18} \mathrm{We}$ will examine how the same process evolved along Durban's polyglot waterfronts. Here, Tamil, Gujarati, Zulu, Tsonga, Makua, Portuguese, Dutch and Chinese-speaking communities made up the 'foreign tongues' our gatekeeper, mentioned above, also disparaged during daily walks around the Point. ${ }^{19}$ But in a settler context like Durban, in which British migrants were numerically significant and controlled the levers of formal power, this produced tensions, if not ironies.

Against this backdrop, Durban became an important crucible for the creation of an aggressive architecture of constraint and surveillance, another - and not necessarily contradictory - feature of Indian Ocean port cities. Patrick Joyce famously showed us how nineteenth-century liberal reformers - drawing from older Cartesian philosophy and the 'Grand Modell' that had earlier made the linear street grid the common form of Atlantic port cities - worked creatively to compel urbanites to be free. ${ }^{20}$ To create cities of selfregulating free circulation, they sought to replace putrid fluids, obstructive flesh and stenches with fresh, transparent, predictable space, waging wars on abattoirs, markets, charnel grounds, traffic, loiterers, jostlers and indeed darkness itself. Metropolitan reformers mapped urban towns incessantly, turning the harsh 'light of publicity' onto them, putting police on the beat, and generating a new moral architecture. Restraint or removal of obstructive humans became imperative. This played out especially vividly in Indian Ocean port cities after about 1850, including Durban.

For our purposes, we consider three aspects. First, everywhere waterfronts - not just port machinery - transformed. Besides the establishment of wide, straight roads, wharfs, promenades and macadamized spaces to impose a linear edge over the mud,

\footnotetext{
${ }^{18}$ Monographs on discrete port cities invariably highlight multiple, overlapping communities in each, but for a start on comparative approaches, see: Pepyn Brandin, Nilkas Frykan and Pernille Røge (eds.), "Free and Unfree Labor in Atlantic and Indian Ocean Port Cities (Seventeenth-Nineteenth Centuries)" International Review of Social History (Special Issue), 64 (2019); John Darwin, Unlocking the World: Port cities and globalization in the age of steam (London: Penguin, 2020), Ch, 6-7.

${ }^{19}$ ARIRD 1902, 8.

${ }^{20}$ Patrick Joyce, The Rule of Freedom: Liberalism and the modern City (London: Verso, 2003).
} 
swamps and siltation of the ever-elusive shorelines, a sea-facing architecture of emphatic lines, incisions and rich ornamentation emerged. ${ }^{21}$ Durban port's now vanished neoclassical and baroque-revival style with occasional 'oriental' motifs, interspersed with vernacular verandas and utilitarian warehouses, synchronised with tropical seafronts elsewhere (even if, with Durban lacking the Indo-Saracenic hybridity of Madras or the neo-Gothic extravagance of Bombay, one needs to look at more eclectic waterfronts of Calcutta, Hong Kong or even Rangoon). As we shall see in the conclusion, Durban's striking innovation was to continue the seaside civilising mission by reorientating its 'seafront' away from wharves toward open, but ethnically exclusive, recreational beaches. It inverted the common notion across much of colonial Asia that hill stations, rather than muggy coasts, provided healthy leisure, sociability and economic opportunity for respectable (white) colonials. ${ }^{22}$

Second, if Durban port's commercial and administrative architecture was 'Maritime Raj' writ small, many carceral structures around Durban's lagoon meant that an oceanwide 'confinement culture' was writ especially large here. ${ }^{23}$ At the broadest level, Durban's developing racial zones echoed, and formalised early on, the ethnic separations manifest in colonial Calcutta, the kampongs of Raffles' Singapore and elsewhere in British Malaya, to highlight obvious examples. ${ }^{24}$ Lazarettos, barracks, gaols, concentration camps, detention hulks and Water Police stations around the lagoon reflected continued diffusion of an Indian Ocean penal regime. As elsewhere, it entailed an idiosyncratic, often archaic, mix of convict labour, racial differentiation and fiscal disincentives, a regime in which incarceration was pervasive and metropolitan reformism rare, and in which police put greatest effort into mobility and labour infractions. ${ }^{25}$ In the

\footnotetext{
${ }^{21}$ There is not yet, so far as I am aware, a volume on comparative seafront architecture in the Indian Ocean World, but the general trends may be easily followed in the relevant regional sections of: G.A Bremmer (ed.), Architecture and Urbanism in the British Empire (Oxford: Oxford University Press, 2016). For a still valuable introduction to Durban, see: Brian Kearney, The Architecture of Natal from 1824 to 1893 (Cape Town: A.A Balkerma, 1973).

${ }^{22}$ An innovative and recent treatment of hill stations is: Nandini Bhattacharya, "Leisure, economy and colonial urbanism: Darjeeling, 1835-1930," Urban History, 40, 3, (2013), 442-61.

${ }^{23}$ For a synthesis by the leading scholars of penal and convict labour regimes in the tropical world, see: Frank Dikötter and Ian Brown (eds.), Cultures of Confinement: A history of the prison in Africa, Asia and Latin America (Ithaca, NY: Cornell University Press, 2007). For a rich example of a single port study, see: Anoma Pieres, Hidden Hands and Divided Landscapes: A penal history of Singapore's plural society (Honolulu: University of Hawai'i Press, 2009). 'Maritime Raj' is Darwin's coinage (Darwin, Unlocking the World).

${ }^{24}$ On the latter, see: David Baillargeon, "Spaces of occupation: Colonial enclosure and confinement in British Malaya," Journal of Historical Geography, 73 (2021), 24-35.

${ }^{25}$ Dikotter and Brown, Confinement; David M. Anderson and David Killingray, "Consent, coercion and colonial control: Policing the empire, 1830-1940,' in Policing the Empire: Government, authority and control, 1830-1940, eds. David M. Anderson and David Killingray (Manchester: Manchester Univ. Press, 1991), 1-17. For examples of local studies elsewhere, see: Prashant Kidambi, “The ultimate masters of the city': Police, public order and the poor in colonial Bombay, c.1893-
} 
wider Indian Ocean, incarceration entwined with prophylactic and public health measures; Durban was among the first ports in the Indian Ocean to set up modern quarantine. ${ }^{26}$

Third, within and between the shadows of these modern institutions, Durban became a prominent site for 'disorderly' practices that another strand of recent scholarship has identified as a constituent part of the imperial Indian Ocean. ${ }^{27}$ Whereas historians have pointed to Durban's place in the circulation of anti-colonial texts in the civic sphere, this piece draws attention to evolving heterotopias along the waterfront. ${ }^{28} \mathrm{We}$ consider, briefly, those isolated yet protean, motley spaces and practices of deviation and subversion, incompatible with both colonial power and formalised resistance: alienated ship-jumpers and deserters, escapologists and stowaways, bribers and counterfeiters, pettifoggers and touts operating (to us) anonymously across the lagoon. If conventional resistance scholarship traces the evolution of coloniser/colonised dialogue, this article highlights a dockside antilogue. But before we get there, let us first set the scene by taking inspiration from the capacious macro-histories of human-ocean interactions by Gillis, Beaujard and Abulafia to get beyond the clichés that societies needed a trading port to be littoral, and that mobility only began in the age of colonial capital. ${ }^{29}$

\section{A DEeP History OF A LAgOON}

The southeast African coast, the Indian Ocean's oldest, is the scar of a Mesozoic mantle plume. 180 million years ago, chimneys of rising rock just north of today's Durban initiated the fracture of the Gondwanaland supercontinent, opening the first isolated basins that, over great time, ocean water filled and submerged. ${ }^{30}$ Recurrent episodes of magmatic swell in the hinterland between about 80 and 2 million years ago produced southern Africa's great interior plateau, over five thousand feet high. The resulting eastward tilt eroded river gorges and incised lagoons, of which Durban's is today among the largest of

1914," Crime, History \& Societies, 8, 1 (2004), 1-21; Aniruddha Bose, Class Conflict and Modernisation in India: The Raj and the Calcutta waterfront, 1860-1910 (London: Routledge, 2018).

${ }^{26}$ See contributions in: Alison Bashford and Carolyn Strange (eds.), Isolation: Places and practices of exclusion (London: Routledge, 2003).

${ }^{27}$ Ashwini Tambe and Harald Fischer-Tiné (eds.), The Limits of British Colonial Control in South Asia: Spaces of disorder in the Indian Ocean region (London: Routledge, 2009); Marcus Rediker, "Afterword: Reflections on the Motley Crew as port city proletariat," International Review of Social History, 64 (2019), 255-62.

${ }^{28}$ See fn. 8.

${ }^{29}$ John Gillis, The Human Shore (Chicago: Chicago University Press, 2012); Abulafia, Boundless Sea; Phillipe Beaujard, The Worlds of the Indian Ocean: A Global History, 2 Vols. (Cambridge: Cambridge University Press, 2019).

${ }^{30}$ Willem de Wet, "Bathymetry of the South African continental shelf" (Unpublished MSc diss., University of Cape Town, 2013), 28-32. 
several hundred on this coast. ${ }^{31}$ Here, a complex interplay between high amplitude sealevel changes and a local northward retroflection of the strong southbound current offshore sculpted the distinctive dunes, swampland and marshes that almost enclose the lagoon. ${ }^{32}$ These same forces have left old, high dunes, which today appear as the forested hills or ridges of the suburbs, younger ones as submerged banks and reefs, occasionally visible as flat estuarine islets. All erode and reform continuously, such that moderns glimpse only a moment in a slow dance of mud, sand and current. To the west, the Berea and Isipingo ridges developed between four and three hundred thousand years ago; to the south the Bluff, a $60 \mathrm{~m}$ high, kilometre-long promontory, pointing like an accusing finger northeast into open ocean, grew from around 100,000 years ago, but took on today's recognisable form only after the Last Glacial Maximum, around 16,000 years before present. ${ }^{33}$

The warm equatorial waters that the southbound current brought to the estuaries were nutritionally rich. The environment attracted some of the earliest humans to an abundance of oysters and mussel shells, whose long-chain fatty acids helped drive a cognitive revolution in our species. Archaeological work around modern Durban finds evidence of consumption and symbolic decoration of shells perhaps as early as 300,000 years before present, but certainly by 90,000 years before and in regular pulses thereafter. ${ }^{34}$ Between 10,000 years ago and the start of the common era, shells from this coastline were being traded (for ostrich shell) with the Lesotho highlands and Tugela uplands, two-three hundred kilometres away. ${ }^{35}$

\footnotetext{
${ }^{31}$ Ander M. de Lecea, Andrew N. Green, and J. Andrew G. Cooper, "Environmental change during the Pleistocene and Holocene: Estuaries and lagoons of Southern Africa," in Quaternary Environmental Change in Southern Africa: Physical and Human Dimensions, eds. Jasper Knight and Stefan W. Grab (Cambridge: Cambridge University Press, 2016), 219-33. ${ }^{32}$ Johann Lutjeharms, The Agulhas Current (Berlin: Springer-Verlag, 2006), 107-20; Andrew N. Green, Nonkululeko Dladla, and G. Luke Garlick, "Spatial and temporal variations in incised valley systems from the Durban Continental Shelf, KwaZulu-Natal, South Africa," Marine Geology, 335 (2013), 148-61.

${ }^{33}$ H.C. Cawthra, R. Uken, and M.N. Ovechkina, "New insights into the geological evolution of the Durban Bluff and adjacent blood reef, South Africa," South African Journal of Geology, 115, 3 (2012), 291-308.

34 There are formidable methodological challenges with the earliest dates. Seemingly Acheulian tools, recovered from beneath the oldest dunes, were excavated before the development of modern dating methods. Oliver Davies, "Pleistocene beaches of Natal," Annals of the Natal Museum, 20, 2 (1970), 403-42. For more certainty, see: Ina Plug, "Aquatic animals and their associates from the Middle Stone Age levels at Sibudu," Southern African Humanities, 18, 1 (2006), 289-99; Marian Vanhaeren, Lyn Wadley, and Francesco d'Errico, "Variability in Middle Stone Age symbolic traditions: The marine shell beads from Sibudu Cave, South Africa," Journal of Archaeological Science, 27 (2019). For the Later Stone Age, see: C. A. Schoute-Vanneck and R. C. Walsh, "The Tongaat Variant of the Wilton Culture," South African Archaeological Bulletin (herafter: $S A A B), 15,58$ (1960), 29-35; C. A. Schoute-Vanneck and R. C. Walsh, "The Umlaas Variant of the Smithfield C Culture," SAAB, 16, 64 (1961), 137-43; J. Kaplan, "The Umhlatuzana Rock Shelter Sequence: 100,000 years of Stone Age history," Southern African Humanities (hereafter: SAH), 2 (1990), 1-94.

${ }^{35}$ Peter J. Mitchell, "Prehistoric exchange and interaction in southeastern Africa: Marine shells and ostrich eggshell," African Archaeological Review, 13, 1 (1996), 35-76.
} 
Eastern African farmers migrated south, many along coastal pathways in Mozambique, in several waves between the third and thirteenth centuries of the common era. ${ }^{36}$ Around 'Durban,' they continued to supplement their livestock and sorghum diet with lagoonal seafood, mined the iron in estuarine marshes and coastal shale outcrops, and built small but semi-permanent homesteads nearby. ${ }^{37}$ By the thirteenth century, the last of the Iron Age arrivals - Nguni-speakers - had probably bequeathed the toponyms still familiar today: isiBubulungu (eminence, promontory), iFenya (marshlands), uThungula (plum bush that grew atop the beach dunes of the Point) and eThekwini (lagoon). ${ }^{38}$ But despite fragmentary signs of transoceanic exchange in the environs of $7^{\text {th }}$ $14^{\text {th }}$ century eThekwini - Iraqi glazed glassware, South Asian beads (likely via Cambay or Negapatam), Indian chicken and rat bones, ivory and copper from the far north - there was seemingly no maritime traffic further south than Chibuene, from where imports were likely relayed overland. ${ }^{39}$ Medieval Arab geographers called the waters off southeast Africa Bahr-al-Zulma, the Sea of Obscurity. ${ }^{40}$ They knew the shores below Madagascar as $a l-W \bar{a} k w \bar{a} k$, a dimly perceived maritime frontier, a zone of heat, darkness and erratic winds and eddies, inhabited by fabulous beings (human trees, sacral maidens, mythical birds and djinns) and enclosed by a land bridge curving east to Sumatra. ${ }^{41}$

\footnotetext{
${ }^{36}$ On coastal pathways see, most recently: Armando Semo, Magdalena Gayà-Vidal, Cesar Fortes-Lima, Bérénice Alard, Sandra Oliveira, João Almeida, António Prista, Albertino Damasceno, Anne-Maria Fehn, Carina Schlebusch, and Jorge Rocha, "Along the Indian Ocean coast: Genomic variation in Mozambique provides new insights into the Bantu expansion," Molecular Biology and Evolution, 37, 2 (2020), 406-16.

${ }^{37}$ For the Early Iron Age, see: "Tim Maggs, Mzonjani and the beginning of the Iron Age in Natal," $S A H, 24,1$ (1980), 7196; Gavin Whitelaw and Michael Moon, "The ceramics and distribution of pioneer agriculturists in KwaZulu-Natal," $S A H$, 8 (1996), 53-79. For the later Iron Age, see: J.F Schofield, "Natal coastal pottery from the Durban district: A preliminary survey," South African Journal of Science, 32, 7 (1935), 508-227; C.A. Schoute-Vanneck, "The shell middens on the Durban Bluff," SAAB, 13, 50 (1958), 43-54; L. Horwitz, T. Maggs, and V. Ward, "Two shell middens as indicators of shellfish exploitation patterns during the first millennium AD on the Natal North Coast," $S A H, 3$ (1991), 1-28; Gavin Whitelaw, "Precolonial iron production around Durban and in southern Natal," SAH, 3 (1991), 29-39. Scholarship published prior to 1980 should be read in conjunction with the dating revision in: Maggs, "Mzonjani," 87-91.

${ }^{38}$ Suggestions that eThekwini derives from 'testicle,' to describe the shape of the bay, are highly speculative. See: Adriaan Koopman, "The names and naming of Durban," Natalia, 34 (2004), 70-87.

${ }^{39}$ Evidence of watercraft this far south is entirely lacking. Our current picture for exchange networks is reviewed in Ashley N. Coutu, Gavin Whitelaw, Petrus le Roux, and Judith Sealy, "Earliest evidence for the ivory trade in southern Africa: Isotopic and ZooMS analysis of seventh-tenth century AD ivory from KwaZulu-Natal," African Archaeological Review, 33, 4 (2016), 411-35. See also: Marilee Wood, Laure Dussubieux, and Lyn Wadley, "A cache of $\sim 5,000$ glass beads from the Sibudu Iron Age occupation," SAH, 21 (2009), 239-61; Paul Sinclair, Anneli Ekblom, and Marilee Wood, "Trade and society on the South-East African coast in the later first millennium AD: The case of Chibuene," Antiquity, 86, 333 (2012), 723-37.

${ }^{40}$ G.R. Tibbets, Shawkat M. Toorawa, G. Ferrand, G.S.P. Freeman-Grenville, and F. Viré, "Wāḳwāk,," in, eds. Encyclopaedia of Islam. Vol. XI, $2^{\text {nd }}$ ed., eds. Peri J. Bearman, Th Bianquis, C.E. Bosworth, E. van Donzel, and W.P. Heinrichs (Leiden: Brill, 2002), 104.

${ }^{41}$ Ibid. The orthodox view in medieval Baghdad that 'southeast Africa' conjoined with 'southeast Asia' survived an important theoretical challenge by the Persian mathematician al-Bīrūnī (fl. 1035 CE). For this debate, see: G.R Tibbets, "The Balkhī School of geographers," in The History of Cartography, Volume 2, Book 1: Cartography in the Traditional
} 
The earliest Portuguese expeditions to Asia aimed for the Swahili and Malabari coasts, tracking far offshore. They leave us little about the lagoon except for the first hydrographic surveys and names for coastal features, seen from afar. ${ }^{42}$ But shipwreck survivors from overladen, late-departing vessels from Cochin and Goa came ashore all along the coast south of eThekwini. ${ }^{43}$ As heterodox parties of a few hundred tramped north in hope of rescue at Delagoa, several assimilated with the small Nguni chiefdoms encountered en route. Near eThekwini between c. 1550 and 1650 were a Malabari, two (west?) African former captives, two Portuguese sailors, a Malay woman, and a Catholic friar. A couple of days sail in either direction lived an Iberian mariner, a young Gujarati, a Bengali, a Javanese lascar, a Portuguese rainmaker, and two Muslims. ${ }^{44}$ In the $1680 \mathrm{~s}$ stranded traders, including aspirant slavers, from England, Holland and France were part of multi-ethnic, if fleeting, settlement at eThekwini, large enough to support a market of a hundred people. ${ }^{45}$ After 1690, seaborne visitors to the lagoon were again few. Later English settler traditions refer to a putative second sailor's encampment in 1699, a polygamous Englishman who refused to leave in 1705, and a sequestered pirate in 1718 , in each case assimilating to Nguni lifeways. ${ }^{46}$

Toward the end of the $18^{\text {th }}$ century, the detail becomes clearer. A palimpsest of clans lived around the lagoon: initially Mpofana and Thembu, subjected by the 1770s to the Thuli paramountcy, itself subordinate in an asymmetrical alliance with the Cele people from the 1790s, the latter having taken leave of ecologically-driven violence between the iMfolozi and uPhongolo rivers to the north. ${ }^{47}$ By the 1810s and 20s, impoverished Zelumu or Nkumbi (wanderers) joined them from the same theatre of conflict. ${ }^{48}$ To various degrees, each depended on the lagoon as a source of food and deployed novel basket or

Islamic and South Asian Societies, eds. J. B. Harley and D. Woodward (Chicago: University of Chicago Press, 1992), 10836.

${ }^{42}$ Portuguese mariners may have known eThekwini as Ponta Pescaria, but there is unsurprising imprecision in the sources. Careful rereading of roteiros and charts suggests Da Gama had named the coast between Pondoland and St Lucia 'Natal' (after a Christmas-time survey) while anchored off modern Hibberdene, not Durban as per popular mythology. See: Gavin Whitelaw, "What Da Gama missed on his way to Sofala," Natalia, 27 (1997), 30-41.

${ }^{43}$ C.R Boxer, "Introduction," in The Tragic History of the Sea 1589-1622, ed. C.R Boxer (Cambridge: Cambridge University Press, 1959), 8, 17-18.

${ }^{44}$ See original accounts in translation in: G.M Theal, Records of South-Eastern Africa (London: Wm. Clowes \& Sons, 1898-1902), Vol. I, 236-8, 251, 283 and Vol VIII, 102-10, 309, 320, 331-5, 349. For a recent modern analysis of shipwreck accounts, see: Elizabeth A. Eldredge, Kingdoms and Chiefdoms of Southeastern Africa: Oral traditions and history, 14001830 (Woodbridge: Boydell \& Brewer, 2015), 54-88.

${ }^{45}$ John Bird, The Annals of Natal, 1495 to 1845. Vol. I (Pietermaritzburg: P. Davis \& Sons, 1888), 25-58.

${ }^{46}$ T. V Bulpin, Natal and the Zulu Country (Cape Town: Books of Africa, 1966), 47-8.

${ }^{47}$ This can be followed in more detail than is possible here in: John Wright, "The Thuli and Cele Paramountcies in the coastlands of Natal, c. 1770-c. 1820," SAH, 21, 1 (2009), 177-94.

${ }^{48}$ Keletso Atkins, The Moon Is Dead! Give Us Our Money! The cultural origins of an African work ethic in Natal, 18431900 (London: Heinemann, 1994), 10. 
'kraal' fishing techniques, while likely also using it, or nearby beaches, for fertility/renewal rituals and emetic therapy. ${ }^{49}$

By now, a community of European merchants and smugglers, a radical extension of the Bombay 'country trade,' had brought a small commercial revolution to Delagoa Bay. ${ }^{50}$ This brought other lagoons along the southeast African coast to merchant attention. In 1824, merchants plying between Mauritius, Delagoa and Algoa ventured to 'Port Natal,' the English name for eThekwini that started appearing on charts in the 1780s. Nominally 'English,' the companies were led by an Irish veteran of the East India Company's Moluccas ventures, a coastal trader recently out of Bengal, a Canadian sailor and the heir of an Anglo-Dutch Jewish family raised on St Helena. ${ }^{51}$ Leading highly creolised parties and winning a grant or cession from the Zulu court - for whom the lagoon was a distant southern periphery - they set up a camp from which to buy ivory with beads, textiles and guns, and dabbled in boatbuilding (claims in the 1980s they were slavers have not survived archival scrutiny). ${ }^{52}$ They took vernacular names, became chiefs and created large polygamous families. ${ }^{53} \mathrm{Law}$ and order were oral, personalised and charismatic. When the houses fell out with one another, they segmented into isolated homesteads, built from wattle and daub, and arranged them in circular patterns. Their dress and food mirrored Nguni custom. But a lightly populated lagoon of creolizing migrants could not last.

\section{The Making of a Colonial Port From 1830}

The lagoon changed in the $1830 s$ s $^{54}$ Port Natal's economy, never flourishing, stagnated for lack of capital and insurance against wreck. The early traders fought over the scraps, and several died before the new decade begun. The families almost abandoned their

\footnotetext{
${ }^{49}$ Gavin Whitelaw, “An Iron Age fishing tale,” SAH, 21 (2009), 195-212. It is uncertain whether a disinclination among certain sections of coastland society to consume marine foods, which is apparent in early ethnological sources, reflected class distinctions (in which reliance on estuarine foods indicated social inferiority) or powerful religious taboo, or some combination.

${ }^{50}$ Chewins, "Trading Societies," 47-73.

${ }^{51}$ The best primary sources are: James Stuart and D. McK Malcolm, (eds.), The Diary of Henry Francis Fynn (Pietermaritzburg: Shuter \& Shooter, 1986); Nathaniel Isaacs, Travels and Adventures in Eastern Africa, descriptive of the Zoolus, their manners, customs, etc. etc. with a sketch of Natal (London: E. Churton, 1836).

${ }^{52}$ Carolyn Hamilton, "“The character and objects of Chaka': A reconsideration of the making of Shaka as "Mfecane" motor," Journal of African History, 33, 1 (1992), 37-63.

${ }^{53}$ Besides the memoirs above, see also: Julie Pridmore, "The wives of Henry Fynn: 'Unwritten but potentially transfiguring texts'? The untold biographies of Vundhlazi of the Zelemu and Christina Brown," Alternation 4, 1 (1997), 73-83.

${ }^{54}$ For the key archive of these well-known political developments, see: Bird, Annals. Vol I and II. For social and cultural aspects, see: Allen Francis Gardiner, Narrative of a Journey to the Zoolu Country in South Africa (London : W. Crofts, 1836); William Clifford Holden, History of the Colony of Natal, South Africa (London, A. Heylin, 1855).
} 
homesteads after Shaka's successor, the more inwardly orientated King Dingane, launched an attack in 1831 (and threatened to again in 1835 and in 1838). But further immigrants arrived that decade. First were thirty English farmer-merchants and their families disappointed with aided immigration schemes to the Cape. Later came a few hundred Dutch-speaking trekkers with their African captives, seeking an ocean outlet for a flimsy republic locked into conflict with the Zulu state. From Zululand, another wave of "wanderers" (or "runaways" as Dingane called them) sought sanctuary in the 1830s; soon 2,000 Zulu-speakers lived around the lagoon. ${ }^{55}$ Then came British administrators from Cape Town and London, drawn in to quell simmering tensions inland and obstruct Trekker claims to a port on the sea-lanes to Asia. Between 1842 and 1845, after long-rumbling tensions and suffering a Trekker-led siege, British forces seized the seaport and proclaimed the Colony of Natal. ${ }^{56}$ During this time, racial hierarchies developed. The Europeans bore with them a mix of Methodist or Calvinist piety, commercial aspirations and hunger for extensive cattle pasture and maize farms inland. Influenced by the early manifestations of race-science then taking shape across the Empire, they disdained intermarriage, organised in racially exclusive civic committees, and started putting in place the pillars of racial segregation that would subsequently transform the lagoon in elaborate ways.

The new colonial government set about a wholesale development project in the Colony. From the mid-1850s through later decades, authorities sold lands and licences from which to raise revenue. They capitalised hinterland agriculture. ${ }^{57}$ Government and private investors experimented with temperate and tropical crops with a view to export. Sugar in the coastlands, and maize and cotton in the grasslands, dominated from the 1860s. By the 1870s and 1880s, huge new urban markets emerged in the northern and eastern boomtowns of Kimberley, Barberton and, largest of all, Johannesburg. ${ }^{58}$ These developments created hinterland dependency on imported materials, foods and consumer goods from which Durban, much nearer than the Cape Ports, sought to profit. As part of these changes, the Natal state developed the lagoon into a port. They designed the new infrastructure primarily to exploit, and increase, the cargo trade. Though the port

\footnotetext{
${ }^{55}$ Atkins, Moon, 22-5.

${ }^{56}$ To appease the Trekkers and provide a more central locus for a dispersed population, the British retained the capital at Pietermartizburg, a hundred kilometres inland, for the new colony.

${ }^{57}$ See contributions by Collenbrander, Ballard and Lenta, Sellers, and Richardson in: Guest and Sellers (eds.), Enterprise, 99-198.

${ }^{58}$ These developments cannot be considered here, but for a recent attempt to integrate diamond, gold and other mining ventures in the late nineteenth-century interior, and the towns that grew around each, see: Jade Davenport, Digging Deep: A History of Mining in South Africa (Cape Town: Jonathan Ball, 2013).
} 
developers could not yet see it, this soon attracted large numbers of migrants of all myriad kinds, both from the hinterland and the sea: they saw the port either as destination or steppingstone. Let us first consider how this infrastructural development evolved.

The earliest commercial stores at the seaward entrance to the lagoon, which coastal inhabitants called 'Sandy Point,' appeared in the 1830s, forming the nucleus of a warehouse node along the landing beach. Among the developers' first significant acts was the fortification of the Point to defend British shipping from naval and landward threats. In 1838, soldiers had cleared mangroves and established a fort upon the Point dunes. By 1845, 'Fort Victoria' was the centre of a modest complex of barracks, stores, and a magazine and Customs House, which guns overlooked from the promontory. ${ }^{59}$ The Point fort hung on until the late 1870s, despite few naval alarms. Later, in response to French activity in Madagascar and the Comoros, and Russian designs on sea-lanes to India in the 1880s, engineers emplaced modern batteries around the Bluff, to be augmented at the outbreak of the South African war in $1898 .{ }^{60}$ By then there was much to protect, notably the Point railway line (opened in 1860 and extended in 1879), a submarine telegraph linking Durban to Port Louis, Aden and Suez (laid in 1879), and a forest of cranes and warehouses. ${ }^{61}$

Charting the lagoon for the safety of cargo ships was also key during the halfcentury after 1850. Early Victorian modernisers had only approximations and sketches of Durban lagoon, mostly concerned with the timber and grazing potential of the hills. ${ }^{62}$ Between 1845 and 1895, a local hydrocracy - to use Hofmeyr's turn of phrase - produced ninety-seven surveys of the lagoon, studying all aspects of its hydrography. ${ }^{63}$ This marine archive formed the basis of detailed, widely disseminated editions of the Admiralty Charts (from 1854) and the African Pilot (from 1861) that radically reduced risk to ship masters.

Durban remained dangerous: 101 vessels wrecked around the harbour entrance between 1845 and $1915 .{ }^{64}$ Besides the immediate loss of life and cargo, wrecks presented fresh hazards and produced unseemly scavenging on the beaches. To mitigate, local pilots

\footnotetext{
${ }^{59}$ For a rare collection of visual material relating to the early Point fort, see: Graham McCallum, "Fort Victoria, Point, Durban": https://grahamlesliemccallum.wordpress.com/2014/12/14/fort-victoria-point-durban/ [Accessed: 19 Mar. 2021].

${ }^{60}$ Ingram, Seaport, 70; Johan Wassermann and Brian Kearney, A Warrior's Gateway: Durban and the Anglo-Boer War, 1899-1902 (Pretoria: Protea, 2002), 24-9.

${ }^{61}$ Pearson, Keyport, 40, 69-72.

${ }^{62}$ For example, see King's chart produced in: Isaacs, Travels, 1.

63 "Annual report of the Engineer in Chief, Natal Harbour Department (hereafter: AREC-NHD), 1894," Natal Blue Book (hereafter: $N B B$ ), 1894 (Pietermaritzburg: Wm. Watson, 1895), C-48. See also: Hofmeyr, Dockside, 14.

64 'Natal Harbour Board: Chairman's Minute (hereafter: NHB-CM), 1886' in NBB, 1886, C-47; Vanessa Maitland, Underwater Heritage Impact Assessment for the Proposed Offshore Sandwinning for Developments within the Port Of Durban, Kwazulu-Natal, South Africa (Cape Town: African Centre for Heritage Activities, 2016), 12-24.
} 
assisted vessels crossing the bar, installed beacons in the late 1840s, a signal and observation station in the 1850s and by 1869 a lighthouse, for a period the only one between Algoa and the Red Sea. In the 1870s-80s, port captains added lifeboats and a 'Rocket House,' a peculiar mechanism that fired rescue cables toward craft in distress. ${ }^{65}$

The most intractable obstacle to shipping was the submarine dune at the lagoon's entrance, which prevented large ships from docking. Suggestions to combine dredging and training walls or piers to amplify tidal scour had first emerged in the $1850 \mathrm{~s} .{ }^{66} \mathrm{But}$ it was only in the 1870s-80s when Durban's colonial engineers - themselves elite migrants with professional connections to myriad ports elsewhere in the colonial oceans ${ }^{67}$ - studied similarly situated Karachi, and devised plans at once practical and cost-effective. ${ }^{68}$

Port modernisation at Durban had opened a market for international shipping firms and with it, migrants of all class and ethnic backgrounds. The numbers are striking. Between 1845 and 1860, only 400 vessels of an average 250 tonnes had called. ${ }^{69}$ These were part of a minor, irregular coasting trade from the Cape or as an occasional stop for boats plying further east. But an English mail service in 1857 (expanded in 1863) put Durban into regular communication with Cape Town, London and Port Louis and, in the 1870s, Zanzibar, Mozambique and Madagascar. More steamship companies entered in the 1880s-90s. Although dominated by Union-Castle, there were over twenty major lines serving South African ports by 1920, while myriad windjammers, tramps-ships and sailboats, operated by innumerable small agencies, remained a significant (and underappreciated) part of port traffic until well into the new century. ${ }^{70}$ Between 1860 and 1900, over 12,000 ships had visited, averaging 2,800 tonnes toward the end of this period. ${ }^{71}$ Durban's connections with the world, and the Indian Ocean in particular, proliferated, as Fig. 1 demonstrates. As we will see in the next section, the development of the port and

\footnotetext{
${ }^{65}$ Ingram, Seaport, 62-4.

${ }^{66}$ Lucille Heydenrich, "Port Natal Harbour," in Enterprise, eds. Guest and Sellers, 17-46.

${ }^{67}$ The precise professional journeys of even the most senior engineers need to be adequately researched, but a preliminary review suggests training predominantly in Scottish, Irish and Caribbean ports, as well as an interest in Colombo and Venice. Working through professional institutions with global reach, the engineers could draw off multiple case-studies and expertise elsewhere.

${ }^{68}$ NHB-CM, NBB for 1885, C-53; Pearson, Keyport, 48.

${ }^{69}$ Yearbook, 1917, 626

${ }^{70}$ Lines that operated at Durban (not always simultaneously) before 1920 were: Bank's India-Africa Line, Blue Funnel, Clan Lines, Commonwealth \& Dominion, Companhia Colonial de Navigação, Deutsche Ost-Afrika Linie, Elder-Dempster, Ellerman-Bucknall, Federal \& Shire, Hansa, Holland-Afrika Lijn, Koninklijke Paket Vaart Maatschappij, Lloyd Triestino, Messagaries Maritimes, Nippon Yusen Kaisha, Osaka Shoshen Kaisha, Peninsula \& Orient, Prince, Robin, ScandinavianSouth Africa Line, Union-Castle and White Star. See: Marischal Murray, Ships and South Africa: A maritime chronicle of the Cape, with particular reference to mail and passenger liners from the early days of steam down to the present (Oxford: Oxford University Press, 1933).

${ }^{71}$ Yearbook, 1917, 626.
} 
increases in shipping traffic revolutionised migration to and through the port, changing Durban from premodern outlier to central node in Indian Ocean networks, and producing an ironic backlash.

\section{'Moths to a Candle': Migration 1850s-1910s}

While engineers concentrated on modernising the port, the number of seaborne voyagers increased exponentially. The extent of migration is complicated to quantify until the later 1890s. The most numerous but least understood of the lagoon's visitors before 1895 were the approximately 380,000 crew who operated on ships there since 1860 ; by the end of this period a third were Asian lascars. ${ }^{72}$ Passengers are harder to track. If one estimates a conservative average of fifty per vessel, whether immigrating, emigrating or in transit, over half a million anchored at Durban in the same period. Of those that landed, the best studied are the 65,000 Indian indentured labourers, from the hinterlands of Madras and Calcutta, who disembarked between 1860-95. ${ }^{73} 5,000$ settler-farmers passed through the Point for the hinterland in organised schemes between 1849 and 1860. The majority came from England, but others were from Mauritius, Holland and the Dutch East Indies, Bremen, Osnabruck and Glasgow. ${ }^{74}$ A further 8,000 arrived on government aided programs between 1876 and 1896, now including Irish and Norwegian parties. ${ }^{75}$ During the Anglo-Zulu War (1879-81), several thousand British soldiers entered through Durban, many of whom remained. African migrants crossed the bar in smaller but not insignificant numbers. About 3,000 recruited men, some from Delagoa Bay, and other libertos (freed slaves) from Inhambane and Quelimane, sailed into Durban to work on sugar farms between 1867-76, and another thousand from Inhambane docked in $1890 .^{76}$ In 1873, a thousand St Helenians landed in a scheme to import servants, farm and railway labourers. ${ }^{77}$ Between 1873 and 1877, 500 liberated 'Zanzibaris' - they were Mukua-

\footnotetext{
${ }^{72}$ Tallied from annual shipping returns in: NBB 1860-1895. For the second figure, nationalities are tallied from AR-IRD 1897-1916 (see below).

${ }^{73}$ Surendra Bhana, Indentured Indians in Natal, 1860-1902: A study based on ship's lists (New Delhi: Promilla \& Co., 1987), 3.

${ }^{74}$ Shelagh O' Spencer, British Settlers in Natal, 1824-1857. Vols. 1-8 (Pietermaritzburg: University of Natal Press, 19812016).

${ }^{75}$ Tallied from annual "Report of the Land \& Immigration Board," NBB, 1876-1896.

${ }^{76}$ Ibid., 1891-92: A61; Patrick Harries, Work, Culture, and Identity: Migrant laborers in Mozambique and South Africa, c. 1860-1910 (Portsmouth, N.H.: Heinemann, 1997), 19-21.

${ }^{77}$ Rebecca Swartz and Johan Wassermann, "“Britishness', colonial governance and education: St Helenian children in colonial Natal in the 1870s," Journal of Imperial and Commonwealth History, 44, 6 (2016), 881-9.
} 


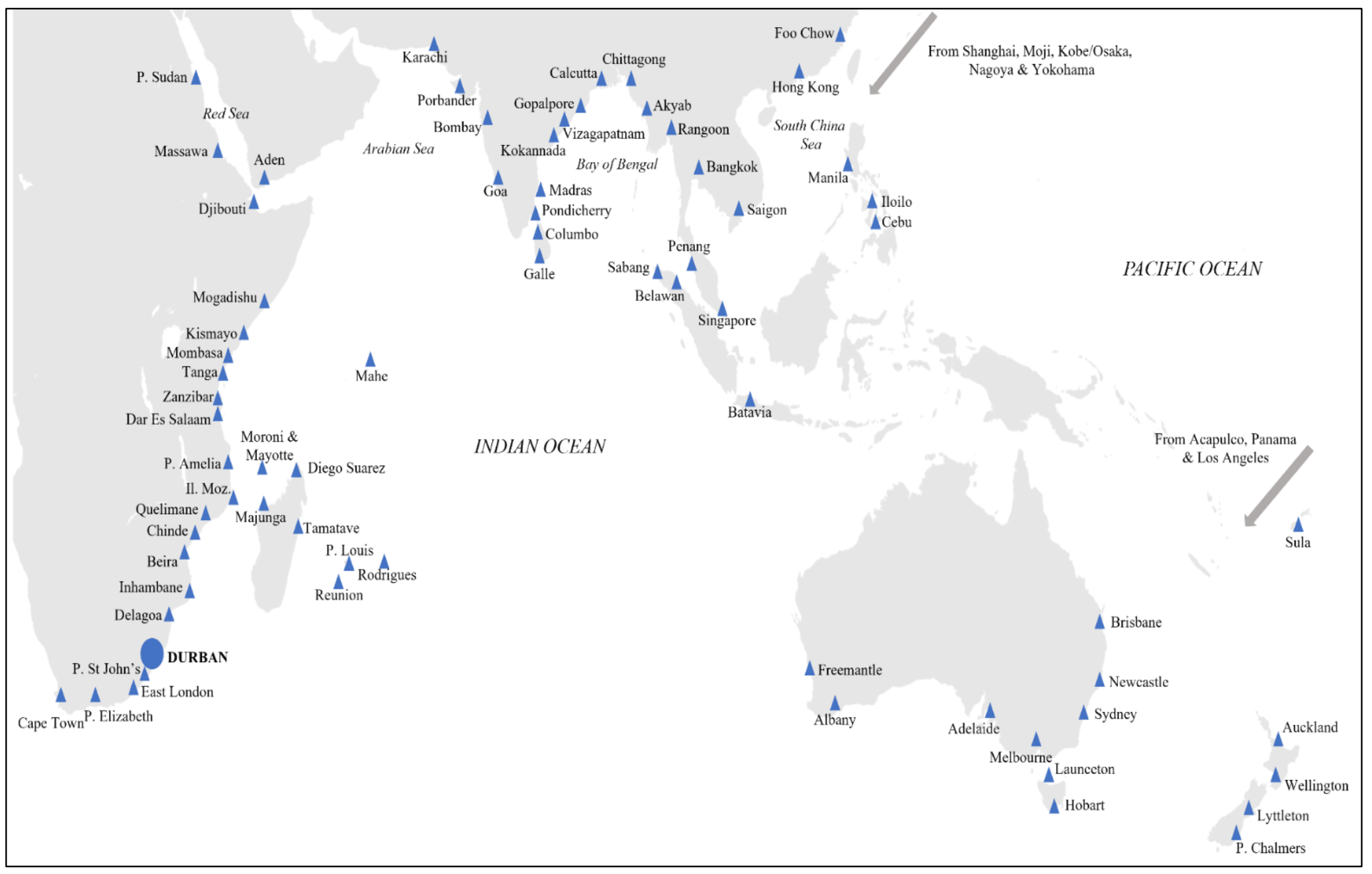

Fig. 1. Indian Ocean Ports of Origin for Ships arriving at Durban, 1870-1910. ${ }^{78}$

\footnotetext{
${ }^{78}$ Drawn from: NBB, 1870-1910. Shipping Statistics, augmented with: Murray, Ships; Data available within: "Shipping Company Fleet Lists," https://www.theshipslist.com/ships/lines/index.htm [Accessed: 19 Mar. 2021].
} 
speakers from Northern Mozambique whom British patrols had rescued from Arab and Comorian slavers en route to Madagascar - walked across Durban's wharves. ${ }^{79}$

Natal Magistrates' annual population returns indicate significant 'independent' migration beyond the organised schemes. The number of Europeans/Whites in Natal, allowing for births, deaths and emigrants, grew by at least 500-600 settlers a year between 1870 and $1890 .{ }^{80}$ But at the end of 1890 , when the Wharfmaster published the first figures on independent European passengers, he found 4,000 'Europeans' had landed during the prior twelve months; by 1896 he had recorded a further $33,000 .{ }^{81}$ Natal authorities believed that between 1870 and 1896, Gujarati family firms totalling about 4,000 individuals had moved through Durban's port. ${ }^{82}$ Using birthplace - rather than more conventional ethnicity or nationality - data from censuses conducted at either end of the 1890s show an even greater heterogeneity in Durban (Fig. 1).

The surge of independent journeys from the 1890s prompted detailed record keeping at the Point. Figs. 2-4 merge all the seaborne voyagers examined while arriving at or transiting through the port from 1897 to 1914. Crews and passage workers remained the most frequent visitors; indenture initiatives expanded to incorporate Chinese 'Transit Immigrants' for the gold mines. We cannot unpack every motivation here. But each stream of 'free' migrants had merchants and peasants, priests and political activists, fugitives and adventurers, those seeking a family and those escaping one. Not included here were the 34,000 officers, servicemen and other 'followers' that entered from Britain and India during Britain's war against the South African Republic (1899-1902), for which Natal was a key staging ground. ${ }^{83}$ All told, the port saw close to two million inward voyagers. As we shall see, this did not please many in authority: Durban's chief constable disparaged the migrants thronging the Point as like 'moths to a candle." ${ }^{84}$

If Durban was a point of entry to the hinterland from 1850-1914, it was also a point of exit. Surveying emigration is even more difficult than immigration. Between 1865 and 1914, approximately 10,000 indentured workers returned to India at the end of their contracts (an additional 35,000 were repatriated between the 1920s to the 1940s). ${ }^{85}$

\footnotetext{
${ }^{79}$ Zubeda K. Seedat, "The Zanzibaris in Durban: A social anthropological study of the Muslim descendants of African freed slaves living in the Indian area of Chatsworth" (Unpublished MA diss., University of Natal, 1973), 1-12.

${ }^{80}$ Tallied from annual "Population" returns in NBB, 1870-1890.

${ }^{81}$ Tallied from annual "Report of the Collector of Customs," NBB, 1891-1897.

${ }^{82}$ Goolam H. Vahed and Surendra Bhana, Crossing Space and Time in the Indian Ocean: Early Indian traders in Natal, a biographical study (Pretoria: Unisa Press, 2015), 31.

${ }^{83}$ Wasserman and Kearney, Gateway, 59-60.

${ }^{84}$ Durban Archives Repository, Durban (hereafter TBD), Durban Borough Police (DBP), Monthly Report for Jan. 1899, 1.

${ }^{85}$ Ashwin Desai and Goolam Vahed, Inside Indian Indenture: A South African story, 1860-1914 (Cape Town: HSRC Press, 2010), 119, 358.
} 
Europeans emigrated in significant numbers, too. Magistrates kept registers of resident Europeans 'born outside the colony.' Between 1870 and 1890 this number remained quite stable despite other sources showing incessant immigration; this suggests 5-6,000 emigrants over the two decades, albeit the returns are incomplete. ${ }^{86}$ Between 1890 and 1896, wharf master records show 29,000 Europeans embarked to leave the colony (whether temporarily or permanently). ${ }^{87}$ No tallies of emigrants appeared again until 1910, when the volume of emigrants equalled that of immigrants. ${ }^{88}$ African emigrants were not uncommon, too. Recruiters returned 12,000 Mozambicans via ship to Lourenço Marques in the $1870 \mathrm{~s}-80 \mathrm{~s} .{ }^{89}$ Up to 400 black South Africans, mostly young Christians and many Zulu-speaking, left for American and British Universities between 1880 and the 1910s. ${ }^{90}$ Recent work indicates some 'Zulu' shipmen worked on international liners, but the number is not clear. ${ }^{91}$

Hinterland turmoil brought to Durban displaced peoples not always reflected in the immigration lists. Zulu-speaking peasants in the colony's interior migrated to Durban from the earliest days, a result of overlapping political, land and subsistence crises at home and bare security and consumer goods available at the coast. 'Refugees,' as colonial authorities called them, arrived regularly, but notable flights occurred during violent succession struggles in the Zulu state in the late 1850s, and in the aftermath of the AngloZulu War (1879-1881). ${ }^{92}$ By the twentieth century, when rinderpest and a suppressed Rebellion intensified the exodus, 'internal migrants' in Durban numbered 12,000 from colony districts, 6,000 from Zululand. ${ }^{93}$ Here they acted as loosely formalised craftworkers, labourers and servants. Meanwhile, 'Free Indians' - that is, contract-expired Indians - had insufficient capital to acquire agrarian property. By 1885, 2,000 small-scale Indian market gardeners had made homes around the port city; by 1900 their numbers had doubled, and their occupations reflected diverse artisans, municipal employees,

\footnotetext{
${ }^{86}$ Tallied from annual "Population" returns in NBB, 1870-1890.

${ }^{87}$ Tallied from annual "Report of Collector of Customs" in NBB, 1891-1897.

${ }^{88}$ Yearbook, 1917, 630.

${ }^{89}$ Harries, Work, 33.

${ }^{90}$ Robert Vinson and Robert Edgar, "Zulus, African-Americans and the African Diaspora," in Zulu Identities: Being Zulu, Past and Present, eds. Benedict Carton, John Laband, and Jabulani Sithole (New York: Columbia University Press, 2009), 242.

${ }^{91}$ John Hyslop, "Zulu sailors in the steamship era: The African modern in the world voyage narratives of Fulunge Mpofu and George Magodini, 1916-1924," Critical Perspectives on Colonialism: Writing the empire from below, eds. Fiona Paisley and Kirsty Reid (London: Routledge, 2013): 124-40.

92 Atkins, Moon, esp. 18-25.

93 By 1900, 'Internal' migrants came from all the colony's districts; most came from Vryheid and Maphumulo. For a full breakdown, see: Hemson, "Class consciousness," 53-54.
} 


\begin{tabular}{|c|c|c|c|c|c|c|c|}
\hline Region & Birthplace & Colony & $\begin{array}{c}1891 \\
\text { Durban }\end{array}$ & Total & Colony & $\begin{array}{c}1904 \\
\text { Durban }\end{array}$ & Total \\
\hline \multirow[t]{14}{*}{ Africa } & Amatongaland & & & & 10 & 413 & 423 \\
\hline & Basotuland & & & & 556 & 43 & 599 \\
\hline & Cape Colony & 2075 & 656 & 2731 & 4442 & 2777 & 7219 \\
\hline & East Coast (Mozambique) & & & & 452 & 543 & 995 \\
\hline & East Griqualand & & & & 6383 & 74 & 6457 \\
\hline & Matabeleland & & & & 3 & 21 & 24 \\
\hline & Mauritius & 568 & 536 & 1104 & 1282 & 408 & 1690 \\
\hline & Orange River Col. & & & & 2313 & 252 & 2565 \\
\hline & Other Parts of SA & 1160 & 156 & 1316 & & & \\
\hline & Pondoland & & & & 528 & 7 & 535 \\
\hline & St. Helena & 242 & 357 & 599 & 501 & 299 & 800 \\
\hline & Swaziland & & & & 1612 & 145 & 1757 \\
\hline & Transvaal & & & & 6215 & 573 & 6788 \\
\hline & Zululand & & & & 218926 & 5300 & 224226 \\
\hline \multirow[t]{19}{*}{ Europe } & Austria & & & & 22 & & 22 \\
\hline & Belgium & & & & 16 & & 16 \\
\hline & Denmark & & & & 143 & 74 & 217 \\
\hline & England \& Wales & 7785 & 3649 & 11434 & 258981 & 10176 & 269157 \\
\hline & France & 53 & 53 & 106 & 369 & 170 & 539 \\
\hline & Germany & 1069 & 135 & 1204 & 1917 & 359 & 2276 \\
\hline & Gibraltar \& Malta & 48 & 34 & 82 & & & \\
\hline & Greek & & & & 140 & 122 & 262 \\
\hline & Holland & & & & 276 & 55 & 331 \\
\hline & Ireland & 728 & 332 & 1060 & 2229 & 827 & 3056 \\
\hline & Italy & & & & 283 & 315 & 598 \\
\hline & Norway \& Sweden & 275 & 235 & 510 & 1342 & 678 & 2020 \\
\hline & Other & 319 & 130 & 449 & 605 & 393 & 998 \\
\hline & Poland & & & & 53 & 38 & 91 \\
\hline & Portugal & & & & 35 & 32 & 67 \\
\hline & Russia & & & & 775 & 441 & 994 \\
\hline & Scotland & 2630 & 1019 & 3649 & 8704 & 4015 & 12719 \\
\hline & Spain & & & & 33 & 12 & 45 \\
\hline & Switzcrland & & & & 101 & 22 & 123 \\
\hline \multirow[t]{5}{*}{ Asia } & British Possessions in the East & 9 & 10 & 19 & & & \\
\hline & China & 44 & 33 & 77 & 202 & 100 & 302 \\
\hline & India & 15763 & 3356 & 19119 & 65720 & 10581 & 76301 \\
\hline & Japan & & & & & 10 & 10 \\
\hline & Other & 12 & 6 & 18 & 69 & 10 & 79 \\
\hline \multirow[t]{3}{*}{ Americas } & Canada & 84 & 38 & 122 & 240 & 101 & 341 \\
\hline & Others & & & & 164 & 74 & 238 \\
\hline & United States & 82 & 48 & 130 & 526 & 271 & 797 \\
\hline \multirow[t]{4}{*}{ Australasia } & Australia & 77 & 63 & 140 & 2861 & 1885 & 4746 \\
\hline & New Zealand & & & & 367 & 197 & 564 \\
\hline & Other & & & & & 7 & 7 \\
\hline & Tasmania & & & & 64 & 38 & 102 \\
\hline \multirow[t]{3}{*}{ Other } & Born at Sea & 38 & 34 & 72 & 58 & 19 & 77 \\
\hline & Unknown/Unspecified & 348 & 82 & 430 & 52 & & 52 \\
\hline & TOTAL & 33409 & 10962 & 44371 & 589570 & 41877 & 631225 \\
\hline
\end{tabular}

Fig. 2. Migrant Population Resident in Natal \& Durban, 1891-1904. ${ }^{94}$

${ }^{94}$ Census of the Colony of the Natal, 1891 (Pietermaritzburg: Government Printer, 1891); Census of the Colony of Natal, 1904 (Pietermaritzburg: Government Printer, 1905). 


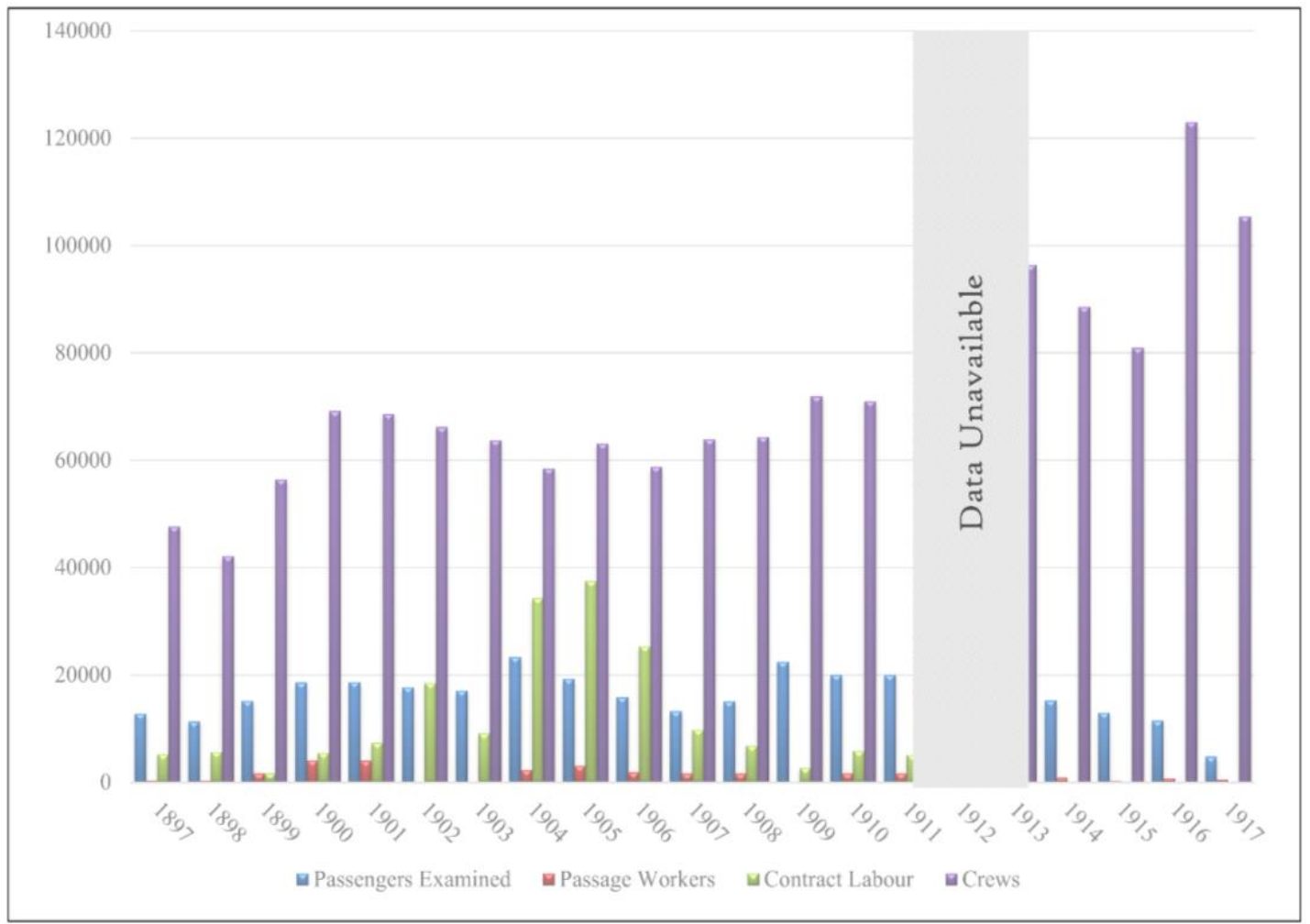

Fig. 3. Inbound Seaborne Voyagers at Durban by Type, 1897-1916 ${ }^{95}$

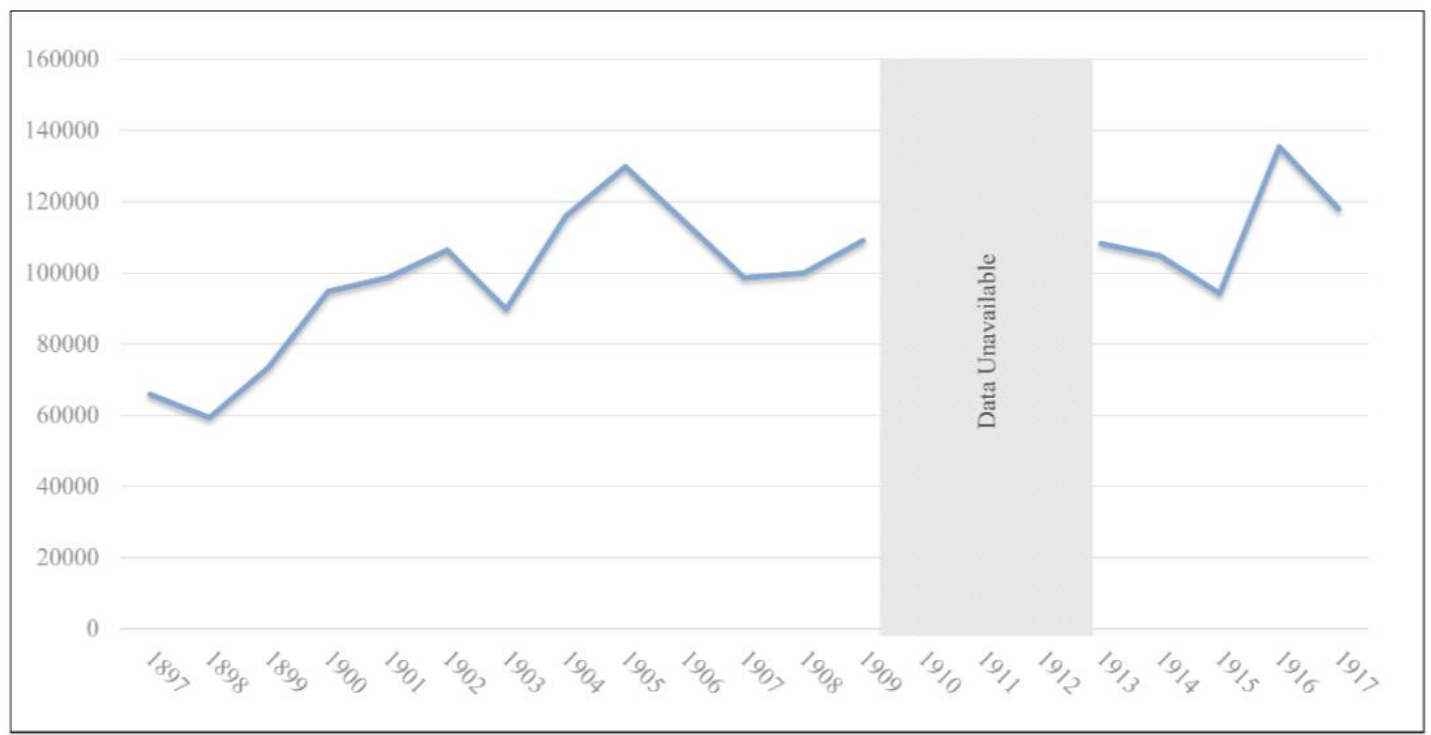

Fig. 4. Inbound Seaborne Voyagers at Durban, Annual Total ${ }^{96}$

${ }^{95}$ Tallied from PAR/AR-IRD, 1897-1916.

${ }^{96}$ Ibid. 


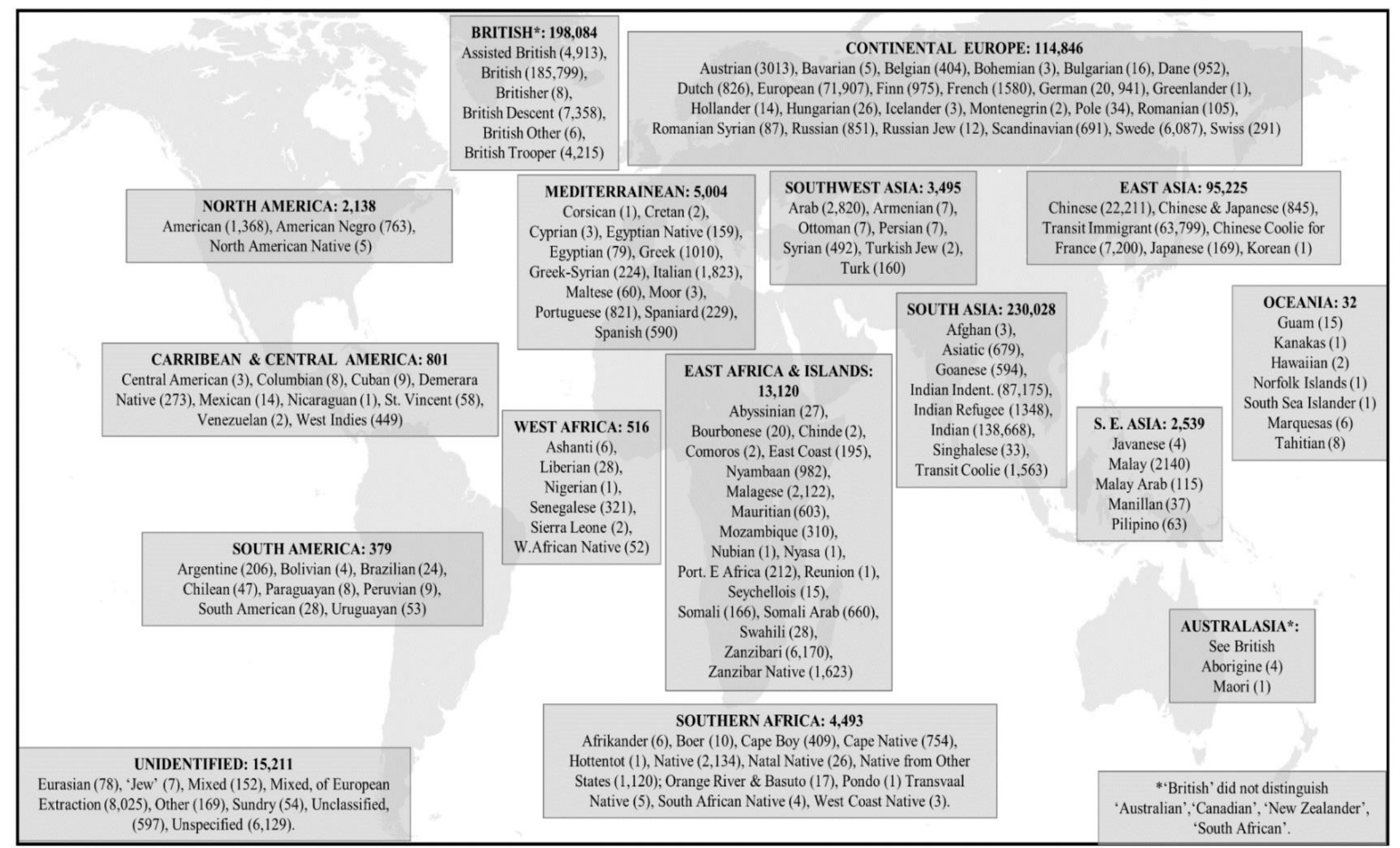

Fig. 5. Inbound Seaborne Passengers at Durban by Nationality, 1897-1916 ${ }^{97}$

\footnotetext{
${ }^{97}$ Ibid. The descriptors are those of the Immigration Department officers, who drew off shipping manifests and passenger declarations.
} 
craftsmen, clerks and hawkers, among others. ${ }^{98}$ The crisis of war in the Transvaal between 1898 and 1902 brought to Durban 24,000 refugees, 12,000 Afrikaner Prisoners of War (for India, Ceylon, St Helena and Bermuda) and, at the peace, 90,000 demobilising soldiers. ${ }^{99}$ The 1904 census captured only a negligible proportion of these flights, but it nevertheless shows Durban had a significant number of residents born elsewhere in southern Africa (see fig. 2).

What did this mean for the banks of Durban lagoon? First, the waterfront became densely occupied. A major node was at the Point. As early as 1853, police noted at 'Back Beach' north of the Point's ocean edge, a multi-ethnic kraal of English and West Indian ship deserters and diverse consorts, a woman named Flatta being their apparently Khoisan matriarch. ${ }^{100}$ A cluster of southern Mozambicans settled a nearby beach hollow in the 1860s. Over the 1870s-80s this area - municipal inspectors called it, perhaps in hope, a 'Cantonment' before settling on 'Bamboo Square' - embraced many migrants. By 1876, it housed 250 people, by 1885 over 500 in 122 homes. ${ }^{101}$ Bamboo Square's inhabitants were about half African of various origins, and the rest made up of Indians, Malays, Chinese, St Helenians and a handful of Europeans around a small mosque. From its earliest days, the families here worked as boatmen, fishers, dock workers and dhobis (laundrymen). Perhaps a fifth sold liquor or sex for a living. Fish smoking sheds appeared on the ocean shore, to provide work and sustenance. ${ }^{102}$ By the late 1890s, six Indian stores (four Muslim, one Hindu, one Christian) were well-enough established to make inclusion into a street directory. ${ }^{103}$ Bamboo Square further attracted a larger transient population. At the turn of the century, three thousand Zulu dockworkers and porters took jobs on this finger of land, most residing in the near vicinity. ${ }^{104}$ A thousand stevedores who arrived in 1903 from Inhambane, Zanzibar and Suez and, at the Point's busy rank, visits from the 10-20,000 Zulu rikisha pullers registered in the city, amplified this core. ${ }^{105}$

\footnotetext{
${ }^{98}$ Surendra Bhana and Joy Brain, Setting Down Roots: Indian migrants in South Africa, 1860-1911 (Johannesburg: Witwatersrand University Press, 1990), 45.

${ }^{99}$ Wasserman, Gateway, 78-80, 114-20, 243-48, 279.

${ }^{100}$ George Russell, The History of Old Durban and Reminiscences of an Emigrant of 1850 (Pietermaritzburg: P. Davis, 1899), 173.

${ }^{101}$ Brian Kearney, “A documentary narrative of the 'Indian and Native Cantonment' at the Point, 1873 to 1903," Journal of Natal and Zulu History (hereafter: JNZH), 20, 1 (2002), $29-63$.

${ }^{102}$ Neelan Govender and Viroshen Chetty, Legends of the Tide: Roots of the Durban fishing industry (Durban: Rebel Rabble, 2014), 66.

${ }^{103}$ Natal Almanac, Directory and Yearly Register for 1897 (Pietermaritzburg: P. Davis, 1897), 870-1, 882

${ }^{104}$ Hemson, "Class consciousness," 61-2.

${ }^{105}$ Ibid., 86; Ros Posel, "Amahashi: the ricksha-pullers of Durban," in The People's City: African life in twentieth-century

Durban, eds. Paul Maylam and Iain Edwards (Pietmaritzburg: University of Natal Press, 1996), 216.
} 
A second node of settlement was to the lagoon's southwest, on Salisbury Island and the Bluff's inward shore. ${ }^{106}$ The waters here had been ideal for fishing since antiquity; lagoon descriptions through the 1820s-50s noted Nguni fish kraals (a submerged a wicker cage or trap). The commercial development of this stretch, too shallow to admit ships, had been slower after a failed 1856 experiment to establish saltworks there. Off-duty indentured labourers and dockhands were wading into the lagoon and harpooning fish at night by 1860 . By 1875 , resident 'Free Indians' had established a seafood market, based on South Indian 'seine' nets, so-called because of their earlier transfer from Paris to French Pondicherry, and a fleet of flat-bottomed masulah boats. They supplied cheap smoked shad, dried sardine (a local variant of Bombay Duck) and shrimp to plantations and working-class markets, as well as medicine to Zulu healers. In years of good haul, they exported to Mauritius. Several master draggers (three from the Pular river south of Madras, a Malabari and a Mauritian) led fishing companies of 15-30 hands each and owned the properties there. They were the area's chief authorities through the 1890s, when the community numbered about three hundred Indians and Africans.

By now, the rescued 'Zanzibaris' (see above) had formed an enclave west of Salisbury Island. A Muslim section lived under the leadership of a Comorian khalifah, Catholics under an Inhambane preacher. ${ }^{107}$ They engaged in market gardening and rented out rowboats across the lagoon; liquor trafficking seems to have been an important income generator too. By the 1900s, previously indentured Francophone Mauritians, as well as other 'East Coast natives' from inland, joined. ${ }^{108}$ Europeans settled here late and only in limited numbers. A lighthouse keeper lived on the Bluff's crest from 1867. Perhaps ten English families, a mingling of mercurial speculators in fish, labour recruitment and wreck salvage, came to make up the bulk below in later years, to be followed by a few independent boatmen. ${ }^{109}$

Separating the Point wharves from the Bluff lay the long arc of malarial swampland of Congella, corrupted from uKhangelaamaNkengane ('Watchers of the Vagabonds'), after a Zulu regiment that putatively encamped there in the 1820s. ${ }^{110}$ Because of Congella's unsuitability for construction, nineteenth-century planners situated the centre

\footnotetext{
106 See: Govender and Chetty, Legends; Brian Kearney, "Salisbury Island: The early years,” JNZH, 31, 1 (2013), 1-21.

107 Seedat, "Zanzibaris," 26-34.

108 Ibid., 32.

${ }^{109}$ For example: Kearney, "Salisbury," 7-10.

${ }^{110}$ There is no evidence that such a regimental outpost ever existed. Koopman resolves the riddle by suggesting Trekker leader Andries Pretorius had appropriated the name of an important Zulu palace and transplanted the toponym to his own small camp at Port Natal in the 1840s. Koopman, "Durban," 82-3.
} 
of the town on firmer soils a few hundred metres northeast, leaving the waterfront here a muddy backwater and public defecation ground. ${ }^{111}$ The few visitors to this stretch came to cut mangroves for termite-resistant building poles, and to strip their bark for its medicinal qualities. Over the 1880s, a straggle of shad curing sheds and lime kilns belonging to a mix of English and Indian owners appeared, but it retained a reputation for marine detritus. ${ }^{112}$ On Congella's western fringe, where the uMbilo river enters the lagoon, Indian market gardeners congregated from the late 1860s. They, probably with Hindus on Salisbury Island, maintained a Shiva Temple - it enshrined the Goddess of Fish and of Smallpox - from 1869 until its destruction by flood at the turn of the century. ${ }^{113}$

\section{The Reign Of THE WATER RATS AND the FASCINATION FRANTIC}

Late nineteenth-century English watercolourists typically omitted any depiction of the unromantic, heterodox world of the waterfront, and instead highlighted the technological progress and natural landscapes around the lagoon. ${ }^{114}$ The artistic erasure was echoed by municipal attempts to scrub the peoples from the lagoon, be they residents or passing migrants. Historians of southeast Africa have long studied the corps of social and public health reformers, employers, intellectuals, and legislators who circulated Eugenic and segregationist ideas from mid- $19^{\text {th }}$ century onwards, winning support from both middleand working-class settler audiences. ${ }^{115}$ Across Natal, this manifested in denunciations of, and ultimately restrictions on, free African and Asian mobility, residence patterns, political rights, consumption choices and domestic/sexual practices. Segregationists encouraged respectable northern European settlement and the upliftment of 'poor whites.' As part of these campaigns, reformers tried to transform Durban into an exemplar of Victorian civic urbanity. ${ }^{116}$ Beginning as early as the 1850 s but in full swing by the 1890 s, Durban's municipal elites waged war on the town's smells, dust, and air. Architects decorated the English-named streets with monumental architecture, splendorous

\footnotetext{
${ }^{111}$ Brian Kearney, “'Keep your town sweet and wholesome.' The inspector of nuisances: A narrative of culture and sanitation in nineteenth-century Durban," Historia, 57 (2012), 42-65.

${ }^{112}$ Ibid., 55. See also: "Report of the Resident Magistrate, Durban Borough, for 1881," in NBB, 1881, JJ-94.

${ }^{113}$ Alleyn Diesel, "The worship and iconography of the Hindu folk goddesses in Natal," Journal for the Study of Religion, 5, 2 (1992), 3-30.

${ }^{114}$ For an anthology, see: Nigel Hughes, The Paintings of the Bay of Natal: A selection of works dating from 1845 to 1982 (Johannesburg: Mertrade, 2001).

${ }^{115}$ For the widest perspective, see: Jeremy C. Martens, “'So destructive of domestic security and comfort': Settler domesticity, race and the regulation of African behaviour in the colony of Natal, 1843-1893" (Unpublished PhD diss., Queens University, 2001).

${ }^{116}$ W.P.M. Henderson, Durban: Fifty years' municipal history (Durban: Robinson, 1904), 225-330.
} 
commercial buildings (shops, railway stations), places of sociability (churches, clubs, schools, libraries, museums), leisure spaces (parks, fountains, cafes, public baths, hotels) and, of course, police stations and prisons.

The Age of Improvement came to the lagoon with attacks on 'eyesores' and 'encroachments.' ${ }^{117}$ First, Durban's powerful Inspector of Nuisances, in collaboration with the Police superintendent and Wharfmaster, tried to displace the families of Bamboo Square, Salisbury Island and Congella. The efforts began early, with injunctions against 'poaching' and wattle and daub construction by the late 1860 s. ${ }^{118}$ They made many subsequent attempts to reduce or remove Asian and African fishermen on conservation or security grounds in the decades that followed. Faced with licencing restrictions on nets and boats, and by outright bans on small craft in certain areas, fishermen's numbers stagnated and then dwindled in the late 1890s. ${ }^{119}$ Harbour authorities soon after built a railway along the Bluff shore, and a mechanised slipway, a coaling dock, and a whaling station.

At the Point, the first demolitions of shanties at Bamboo Square occurred in 1879. Remaining inhabitants received eviction notices in periodic waves in the 1880s-90s, their execution delayed by jurisdictional confusion and the cost of removal. ${ }^{120}$ It took an outbreak of plague in 1902 to force wholesale clearance. Destruction also took place at Congella in 1880, but the most significant intervention here began in 1896 with a land reclamation and associated channel dredging project, to open an embankment named after Victoria. By 1907, contractors had covered 94 acres of swampland with rubble and dry sand and had built a 500-metre wharf extending the usable harbour westward. ${ }^{121}$ Port regulations, first formulated in the 1860s and expanded each decade thereafter, show the sanitary impulses that prevailed over the new wharves. ${ }^{122}$ These included regular fumigation, fines for defecation and urination, installing offal bins, destroying stray dogs, and a tarring program to relieve the Point's 'disgraceful condition of roads.' 123

A second development during this period was that the Harbour Board and municipality extended ownership over emergent spaces. They sold or leased plots to

\footnotetext{
117 “NHB-CM for 1885, , NBB, 1885, C-57.

${ }_{118}$ Charles Fitzwilliam Cadiz (ed.), Natal Ordinances, Laws, and Proclamations, Vol 1. (Pietermaritzburg: Govt. Printers, 1890), Law 8/1869. See also: Brian Kearney, Stern Utility: The wood and iron architecture of Natal (Durban: SelfPublished, 2014), 24.

${ }^{119}$ Govender and Chetty, Legends, 82-8.

${ }^{120}$ Kearney, "Documentary," 39-40, 55-60.

${ }^{121}$ Pearson, Keyport, 110.

${ }^{122}$ Cadiz (ed.), Ordinances, Vol. I, Law 17/1863, Vol III, Law 29/1880.

123 “NHB-CM for 1887,” NBB, 1887, C-40.
} 
Anglophone business interests, Christian philanthropic organisations, and racially exclusive leisure concerns. Point Road became a modern commercial avenue by 1880 , with a railway station and several importers clustered at the tip of the Point. By 1897, a street directory shows 300 offices and homes inhabited by many marine services (boat repairers, chandlers, clerks, surveyors, engineers, master mariners, mechanics, pilots, sailmakers, stevedores and tidewaiters) and in retail (general dealers, grocers and outfitters). ${ }^{124}$ Timber and sugar firms occupied the western parts of reclaimed Congella after 1906; boat repair works and coal suppliers filled the Bluff shore.

Christian philanthropy came to the Point as early as 1863 with a rudimentary 'Sailors' Church' (1863) and a Wesleyan Methodist chapel (1865). ${ }^{125}$ Two hospitals, the first between the Point and Congella (1861) and a second on flattened dunes at Back Beach (1879), entrenched the sense of mission. ${ }^{126}$ These impulses grew more pronounced with Marie Schultz's informal sailor's home (1877), Seaman's Institute (1888) and Sailor's Rest (1889), as well as a small school at Bamboo Square (1884) and another joint EnglishTamil class at Salisbury Island (1880). Both the Durban Benevolent Society and Scottish Free Masons were active in the 1890s.

Leisure facilities began with a bathing 'stage' (Archie's Hencoop, 1857), Royal Natal Yacht Club (1863), Durban Rowing Club (1874) and Point Yacht Club (1892); the clubhouses of each shifted several times around the northern shores of the lagoon. ${ }^{127}$ At Salisbury Island, pleasure ferries and weekend houseboats existed in the late 1890s. Hotels and cafes appeared, though in fewer numbers than we might expect of a waterfront. ${ }^{128}$ The most conspicuous hotels at the Point were the Alexandra (1879) and Criterion (1889); on the new embankment, the ornate Marine (1896). The reclaimed land became the Esplanade, with an agreement to protect its promenades and gardens from industrial construction. ${ }^{129}$ A first-class Tea House on the Bluff side of the entrance channel opened at the turn of the century, and the municipality erected a fountain and clock named after Da Gama at the Point. A 'Jetty Tea Room' covered part of the landing stage. So wholesome had the atmosphere become, that a Professor of Music and a Gentleman took residence on the street. ${ }^{130}$ Meanwhile, the Beach Tea Room, offering a ladies' reading

\footnotetext{
${ }^{124}$ Almanac for 1897, 125-64.

125 Kearney, Utility, 23.

${ }^{126}$ M.G Pearson, "History of government hospitals in Durban, 1858-1945," South African Medical Journal, 35, 3 (1961), 448-50.

127 Pearson, Keyport, 142-8.

${ }^{128}$ Ian Morrison, Durban: A pictorial history (Cape Town: Struik, 1987), 90-107.

${ }^{129}$ Pearson, Keyport, 146.

${ }^{130}$ Almanac for $1897,130$.
} 
veranda and bathing enclosure, brought bourgeois civility to Back Beach, where a few settler enthusiasts pursued open ocean swimming in the 1890s. ${ }^{131}$

The third development was that port authorities created a reception, detention, and policing infrastructure. The routinization and surveillance of seaborne visitors had already been underway since the late 1840s. Port Captain's lighters had met vessels, often stranded by the bar, and lowered passengers in a large wicker 'basket' to ferry them to a landing jetty at the Point. ${ }^{132}$ The earliest arrivals approached a simple timber cabin guarded by armed soldiers, for inspection and clearance. In 1849, the Port authorities opened a Customs House, a large, double-A frame brick construction, its white plaster and tower bell dominating the approach by land or sea. A little further down the Point's track was a reception depot, the first a prefabricated circular warehouse (1849), the second a 'wooden barracks lodged in the bush' for Europeans, operating until the late 1860s. ${ }^{133}$ For those who could afford it, several modest boarding houses offered accommodation.

Waterfront policing became more visible thereafter. In the $1850 \mathrm{~s}-60 \mathrm{~s}$, authorities had charged 'ship-jumpers' and wharf 'vagrants' (as well as petty pilferers and illicit grog sellers) at the central station. ${ }^{134}$ But in 1870 , they established a dedicated Point Road station and, eight years later, shifted into a larger construction, eventually adding a bellfry in 1889 to ring out the 9pm curfew (lamps on the wharves helped). The colony organized a fleet of Water Police - they called themselves Water Rats - to deepen surveillance powers over the lagoon. ${ }^{135}$ They formed in 1877; within half a decade a subbranch opened at Congella and constables patrolled Salisbury Island. ${ }^{136}$ The Water Police were amateur in their early days: in 1883 its superintendent faced 'rumours to his discredit' and censure for 'insulting behaviour,' while he dismissed constables for being 'addicted to drink, more or less.' ${ }^{137}$ But in the mid-1890s, the judiciously named Inspector Fairlie reorganised them into a professional body of forty men.

The Water Rats scurried about the port on a wide variety of duties to maintain the new order, ranging from cargo storage regulations to the detection of labour and immigration infractions. Their growing vigour reflected in the increasing number of arrests, from about a hundred each year in the early 1880 s, to six hundred a year by the

\footnotetext{
${ }^{131}$ Ingram, Seaport, 170.

132 For a description, see: Russel, Durban, 183-189.

${ }^{133}$ Robert James Mann, The Emigrant's Guide to the Colony of Natal (London: Virtue \& Co., 1868), 180.

${ }^{134}$ Jack Jewell, A History of the Durban City Police (Durban: City Council, 1989), 11-12.

135 "Durban Water Police," Nongqai (Apr. 1917), 216.

${ }^{136}$ For a single source overview, see: H. P. Holt, The Mounted Police of Natal (London : John Murray, 1913), $342-7$.

${ }^{137}$ NAB/Colonial Secretary's Office (hereafter: CSO) 2553 C56/1878 Report of Collector of Customs; NAB/Natal Harbour Department (hereafter: NHD) I/2/2 NHB22A/1883 Memorandum from D. Nolan, undated, 1883.
} 
late 1890s. The great majority of apprehensions were for desertion, liquor dealing, pilfering and contract breaking. The remainder - for assault, breach of peace, wharf obstruction, illegal fishing, vagrancy, careless driving, forgery, smuggling, resisting arrest, cruelty to animals, poaching, and unlicenced hawking - help paint a picture of the wharves. ${ }^{138}$ That Water Rats underwent ju-jitsu training spoke of the muscular nature of the job. ${ }^{139}$ Two-thirds of the force comprised Zulu and Indian constables. Because Europeans refused to consent to an examination by African constables, the latter deployed mostly to check dockworkers, but occasionally upturned hierarchies by arresting stowaways and escapees. The multi-ethnic force used rowboats to nose around the bay (they eventually invested in a motorised launch). Their semi-nautical uniforms (blue or white jacket with gilt buttons, gold, or silver cuffs, braided cap), distinctive craft and brightly painted jetty near the landing stage were symbols of a new estuarine authority. ${ }^{140}$

The Point's landing stage also underwent architectural renewal in the last decades of the nineteenth century. Authorities demolished the old Customs House and replaced it with an altogether grander monument in 1880, an elevated neo-classical facade topped by a pagoda-like structure, such 'vaguely Chinese' elements not uncommon elsewhere on the Durban seafront. ${ }^{141}$ They set this hybrid statement back from the wharf as a precaution against destructive tides. In the intervening space, harbour engineers laid concrete platforms, erected a new pontoon and the first iron- sheeted 'shed', a few hundred feet long (Shed A, 1882), to give passengers a functional welcome. ${ }^{142}$ They later built a second (Shed B, 1891) and converted it into baggage and waiting room. Three similar caverns (Sheds C-E) were added by 1901, for mixed cargo-passenger use. The 1903 construction of both a Water Police station and new Police Station just behind the Customs House reiterated the force's presence on the waterfront. With striking columned domes that echoed the pervasive chattris of the Raj, these were imposing, three-story omniopticons for wharf peoples to see, and indeed from which to be seen. We can follow this transformation in figs. 6-10.

Architects had built other less photographed structures, for the ports' less wanted voyagers, throughout the second half of the century. When cholera morbus broke out in

\footnotetext{
${ }^{138}$ See: Annual "Report of the Resident Magistrate, Durban Borough" in NBB, 1880-1886; Annual "Report for the Chief Commissioner of Police (AR-CCP)," NBB, 1896-1899.

${ }^{139}$ Holt, Police, 346.

${ }^{140}$ NBB, Annual Report for the Chief Commissioner of Police for 1896: FF-40.

141 “AR-CCP for 1884," NBB, 1884: B-7. See: Désirée Picton-Seymour, Victorian Buildings in South Africa, including Edwardian \& Transvaal Republican Styles, 1850-1910 (Cape Town: A.A Balkema, 1977), 245-9.

142 “AREC-NHD” in-NBB, 1890, C-48; 1894, C-47; 1896, C-39.
} 
Mauritius in 1854-55, Durban's British guardians already had a prophylactic archive to study. Britain itself had experimented with quarantine systems for two or three hundred years. Colonial initiatives had intensified in Gibraltar, Malta, and Corfu after the Napoleonic Wars (part of pan-European cordon sanitaire on the edge of the Ottoman Mediterranean). ${ }^{143}$ Cape Town's governors had argued against communication with passing slave ships on contagious disease grounds in 1812 and elaborated a set of general quarantine laws in $1827 .{ }^{144}$ Natal followed in 1854, helping to further disseminate measures that became commonplace around the Indian Ocean and Red Sea in later decades. These included the proclaiming of infected ports (with measles, smallpox, cholera or yellow fever), issue of Health Certificates, the flying of a yellow flag until granted pratique, and the compulsory isolation of affected vessels, under threat of heavy punishment. ${ }^{145}$ Durban differed from Cape Town in being the first to construct a lazaretto, or quarantine depot, on the shore in $1860 .{ }^{146}$ Little more than a rudimentary encampment at the Bluff's foot, indentured Indians were its earliest occupants. Harbour officials needed it sporadically until they decommissioned it in 1898; they then used a mix of floating 'plague hulks' and a larger station on Salisbury Island. ${ }^{147}$

Because quarantine measures required a demonstrable outbreak, other sites of isolation appeared around the lagoon for more routine disembarkations. Indentured workers had begun their incarceration under the watchmen of the Calcutta and Madras depots. Entry there had involved medical examinations, the habituation to a prison-like regime and collecting photographs and later fingerprints. This culminated with the issue of a dhoti, bowl and 'tin-ticket,' a metallic passport worn about the neck, to mark their status as controlled labour on arrival. ${ }^{148}$ At Durban, harbour staff built a barracks on the Bluff for the first shipments in 1860 (and enclosed it with a higher wall in 1862) where immigrants stayed for up to three months to await assignments. ${ }^{149}$ Around 1864, a new depot on Benthamite lines opened at the Point 800 metres west of the Customs House. This remained in use until the early twentieth century, in parallel to the much larger, and better studied, 'Magazine barracks' (1880) north of the town.

\footnotetext{
${ }^{143}$ Bashford and Strange (eds.), Isolation.

${ }^{144}$ Government Gazette [of the Cape Colony] (30 Nov. 1827), 1; Grahamstown Journal (23 Jan. 1840$), 2$.

145 Cadiz (ed.), Ordinances Vol 1: Ord. 4/1854, Ord. 3/1858.

146 Pearson, Keyport, 44. Cape Town used Saldhana Bay, a hundred kilometres north, for a quarantine station from 1870.

${ }^{147}$ Kearney, "Salisbury Island," 5; NAB/NHB II/1/41 HDE 449/1902 Correspondence of Superintendent of Water Police, 1902.

${ }^{148}$ Desai and Vahed, Indenture, 52-55.

${ }^{149}$ Ibid., 63-4, 91.
} 


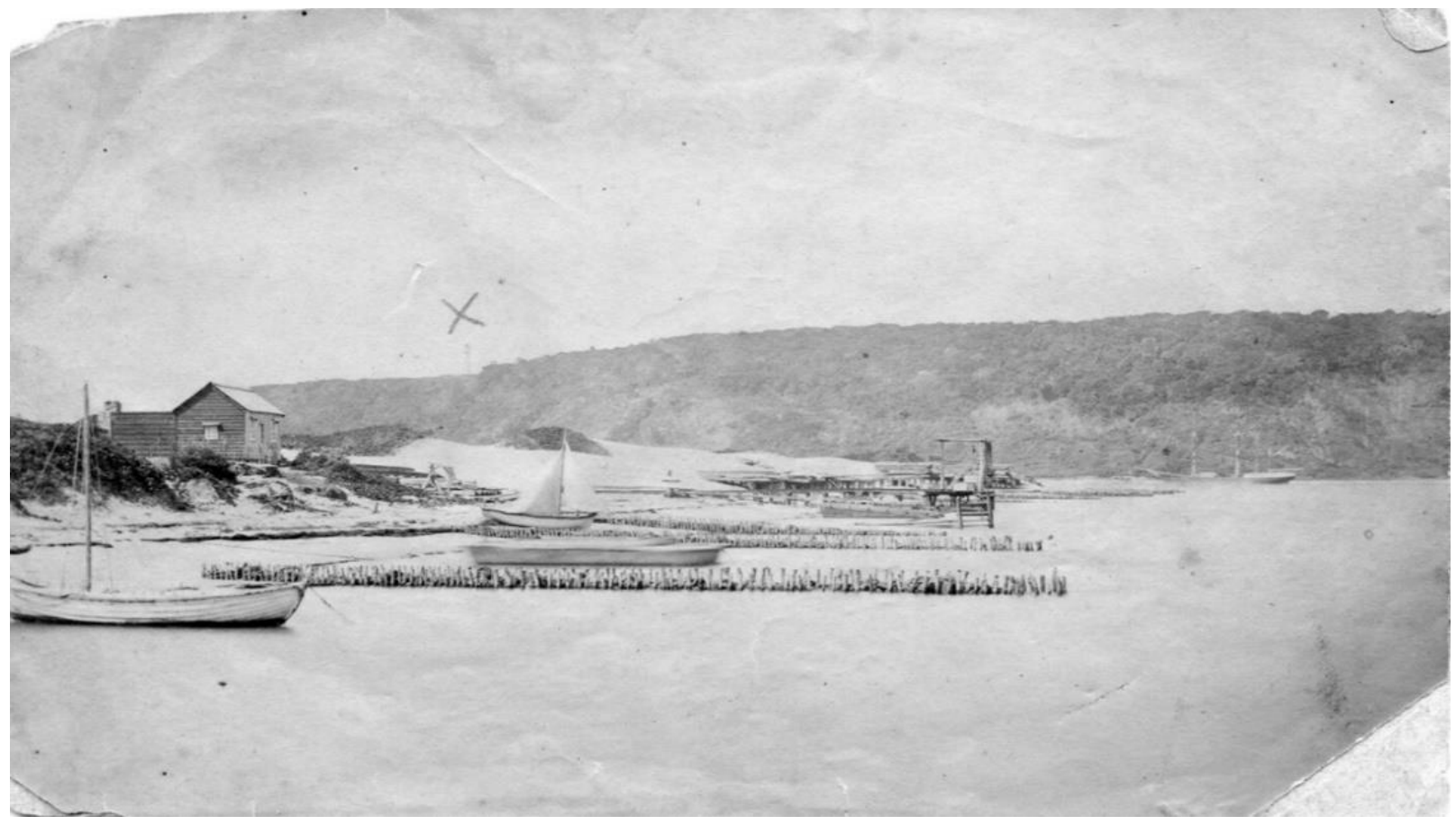

Fig. 6. 'Durban, Pay Office at the Point,' late 1840s. ${ }^{150}$

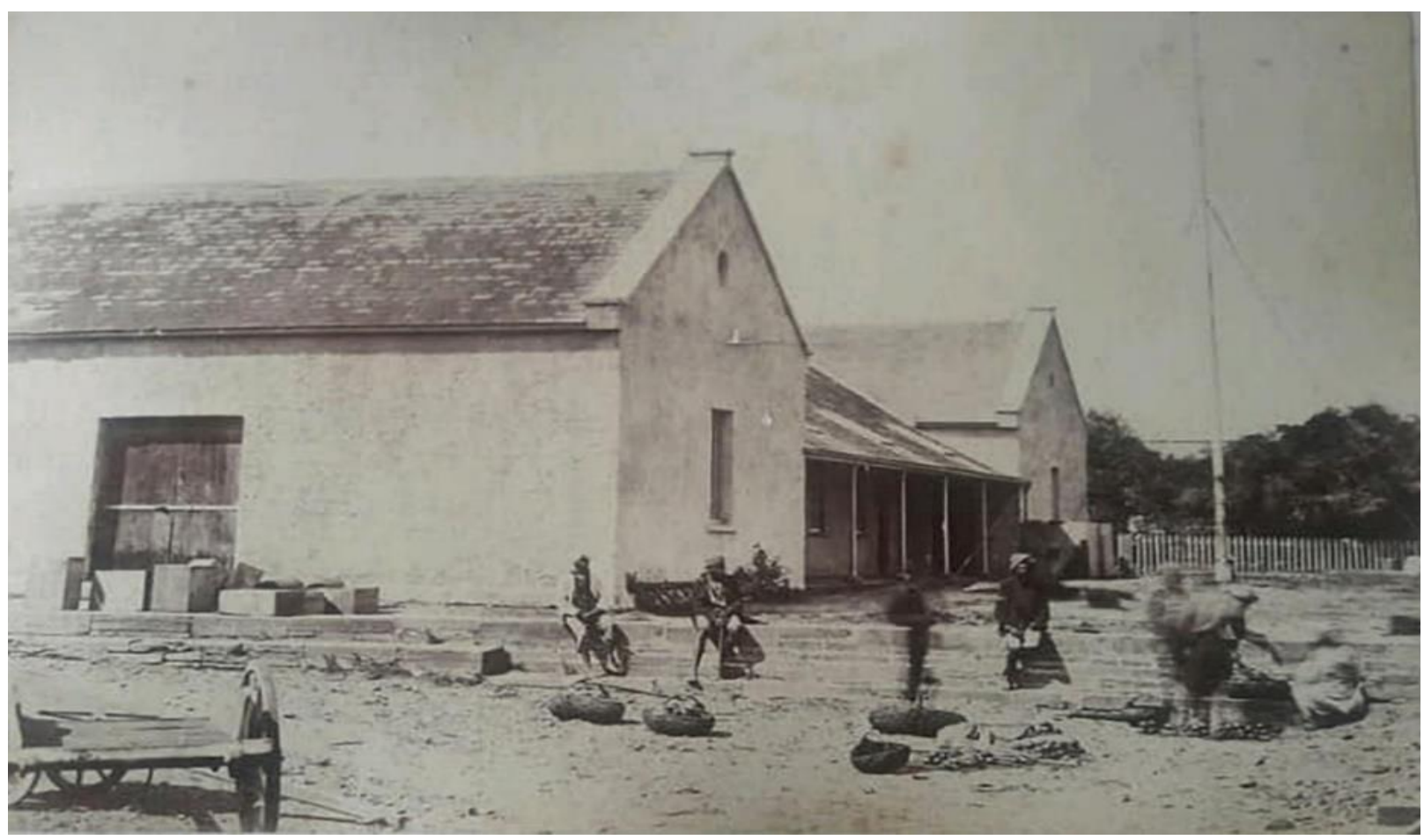

Fig. 7. 'Customs House,' c. $1870 .{ }^{151}$

${ }^{150}$ Digital Railway Images of South Africa Database (DRISA) / Transnet Heritage Library Photo Collection(THL)/South African Railways Publicity and Travel Department (SAR-TD)/LS Collection/Ref: ZA 0375-PB-PB2931_003. Reproduced with kind permission.

${ }^{151}$ Sidney Turner family papers, private collection. Reproduced with kind permission of the owners. 


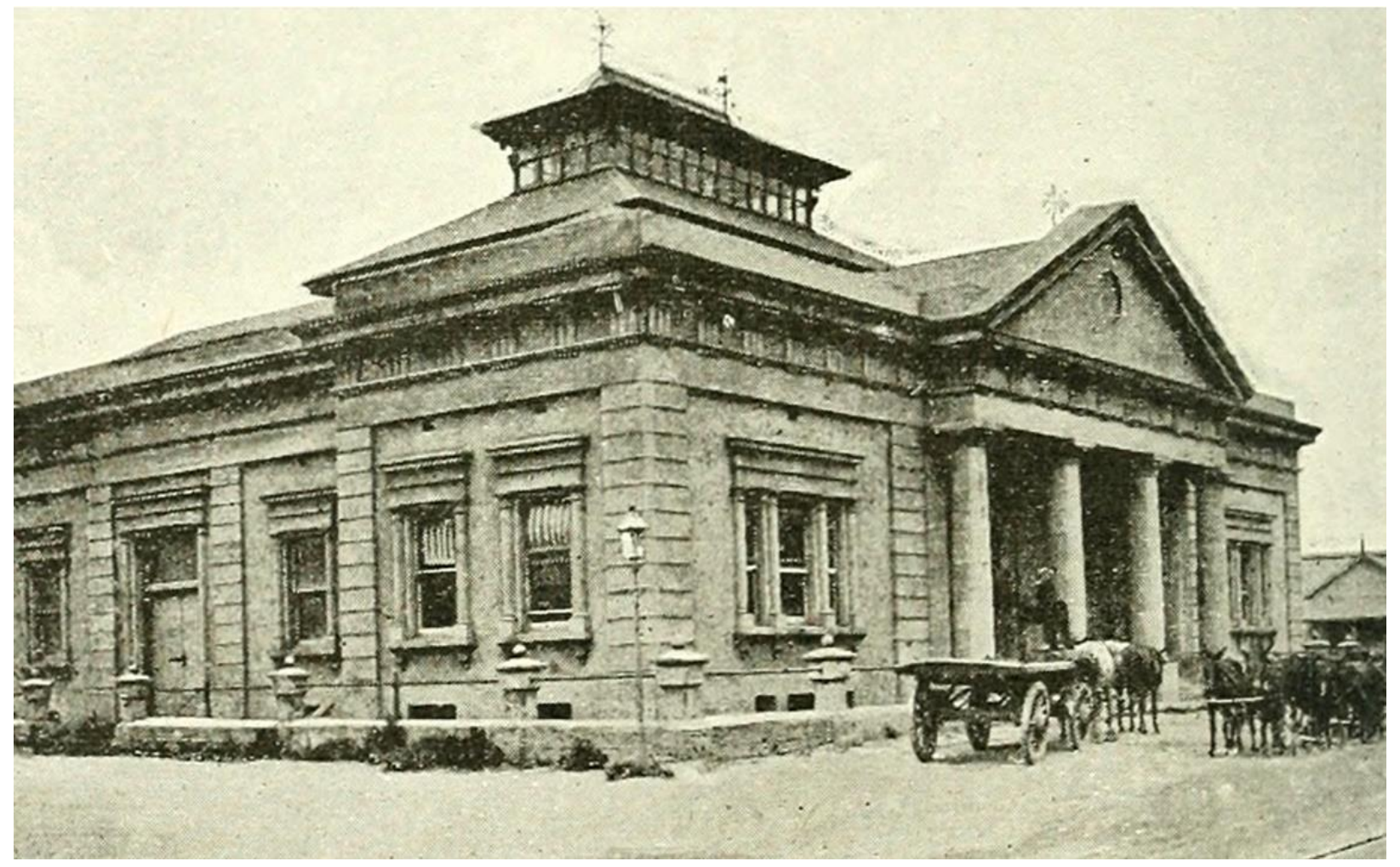

Fig. 8. 'New Customs House, Point,' c. 1894. ${ }^{152}$

The Indian camps were only one of several labour-control structures to emerge at the waterfront. African migrants to the city came under pervasive scrutiny from 1868 , when they were required to carry passes, wear badges, and obey a night curfew. By 1871, about 5\% of Durban's Africans had suffered arrest; by the turn of the twentieth century, the figure was closer to fully $40 \% .{ }^{153}$ During this period, offenders travelled in chaingangs each day from Durban's overcrowded central goal to break and cart stones for the retaining walls, and to flatten the dunes on which so much construction depended. ${ }^{154}$ For workers who avoided the dragnet, the first municipal African barracks - designed on the lines of Victorian workhouses - opened at the Point in 1878, and another opened on the seaward edge of Bamboo Square in 1893. Meanwhile employers, with official's encouragement, built their own barracks. The best known by the 1890s were

\footnotetext{
152 J. Forsyth Ingram, The Colony of Natal: Official illustrated handbook and railway guide (London: J. Causton \& Sons, 1895), 88. Public domain.

${ }^{153}$ Hemson, "Class consciousness," 19, 26-8, 98-9.

${ }^{154}$ Paul Swanepoel and Stephen Peté, "The development of racially defined punishment in colonial Natal: The early history of Durban's Point Prison,” Fundamina, 25, 2 (2019), 169-98.
} 


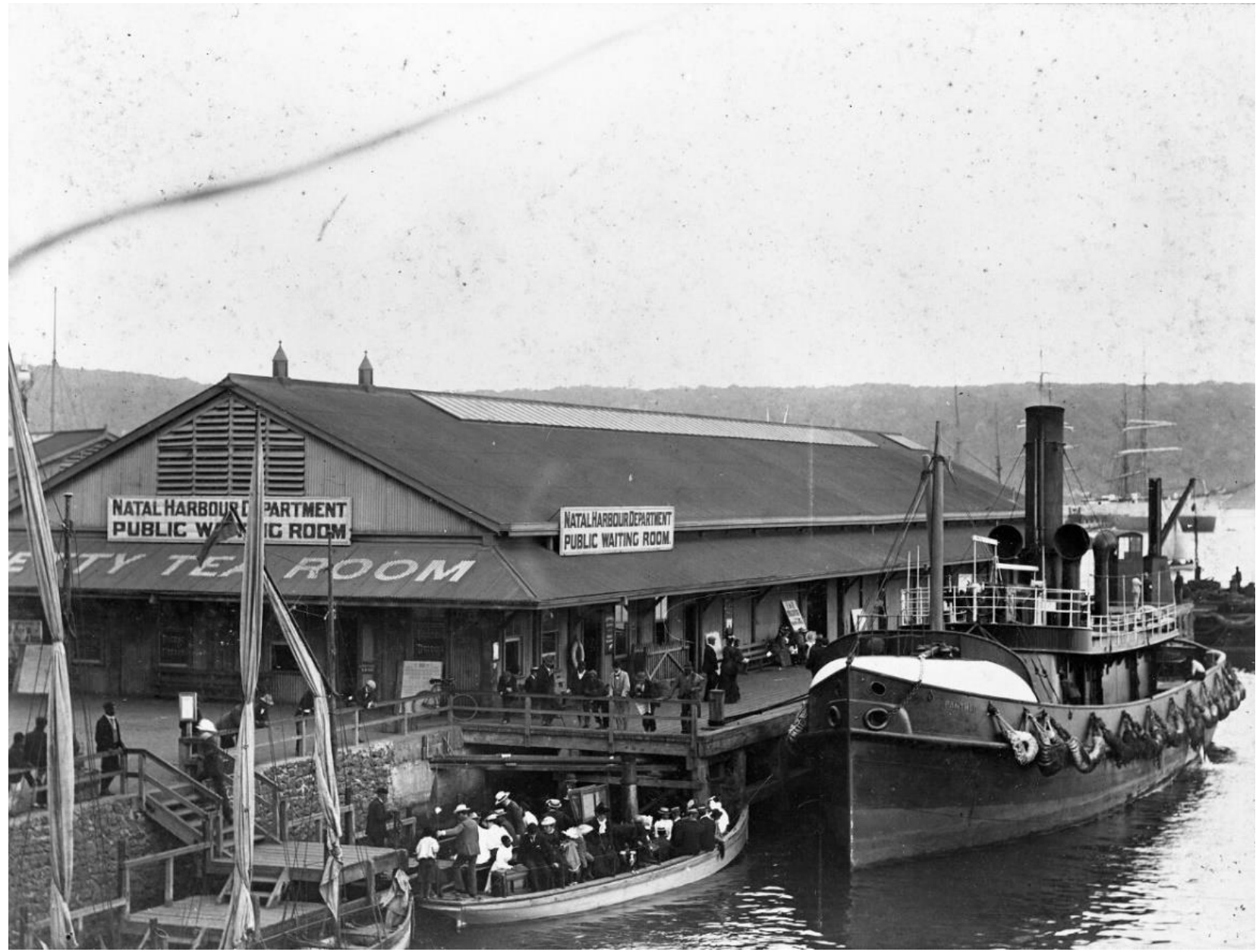

Fig. 9. 'Durban, Jetty Tea Room, etc,' c. 1901. ${ }^{155}$

Benningfield's Mozambican depot on Salisbury Island, and at the Point, those of the African Boating Company, the Union Castle Line, Lloyd's Rickshas and Natal Railways. ${ }^{156}$

When war broke out in the Transvaal in late 1899 and fuelled a coastward 'rush' of refugees, it was axiomatic for port authorities to inter the displaced. ${ }^{157}$ When loyal, or at least neutral, evacuees from Johannesburg arrived and overwhelmed the town's hotels and philanthropic homes, the African Boating Co. availed its Point barracks to European women and children. The Harbour Department meanwhile helped set up a 'Canvas Town' - that is, a grid of guarded tents - at Back Beach. There they put men, whom they feared as potential vagrants, to work on dune and bush clearing at the Point, at drainage works

\footnotetext{
${ }^{155}$ DRISA/THL/SAR-TD/LS Collection/Ref: ZA 0375-PB-PB2931_003. Reproduced with kind permission.

${ }^{156}$ Kearney, "Nuisances," 50.

${ }^{157}$ For further details, see: Wasserman and Kearney, Gateway, 24-303.
} 


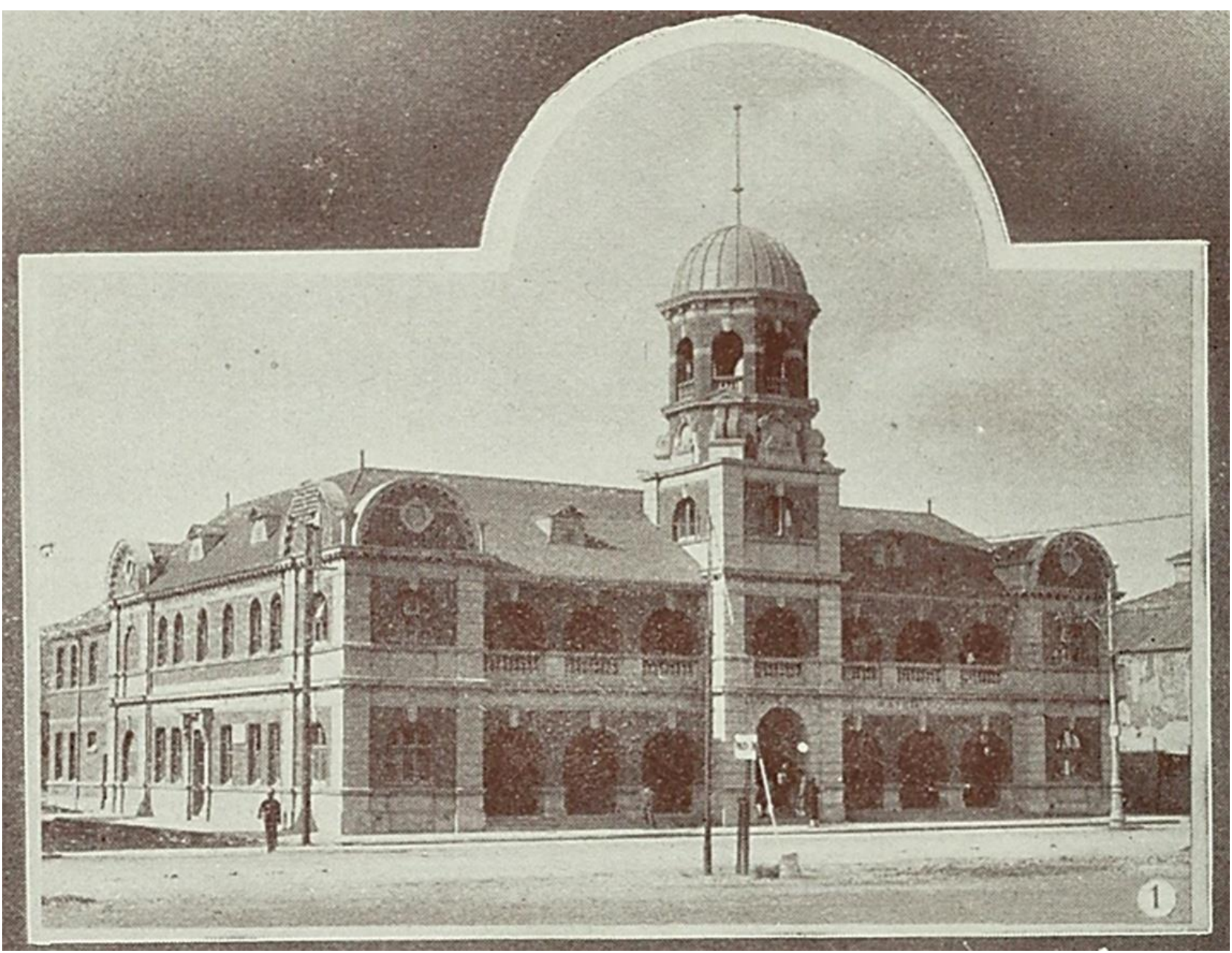

Fig. 10. Water Police Station, c. $1910 .^{158}$

near Congella or as orderlies on hospital ships. Port and military officers co-operated to house enemy combatants in the dock sheds and prison hulks. In 1902, they created a concentration camp capable of housing 1,400 Afrikaner prisoners of war on the edge of the Congella swamps. Afrikaner civilian refugees went to three more camps situated on the southern side of the Bluff. One of these, Jacobs, became a two-day home for 65,000 Chinese indentured miners during the 1904-10 scheme; armed police at the jetty and on trains provided the escort. ${ }^{159}$

The hinterland disturbances at the turn of the century also displaced Africans. The military, acting under Martial Law, entrapped four hundred African suspect collaborators (with Transvaal forces) in a camp on the Bluff, from where inmates provided a pool of

\footnotetext{
${ }^{158}$ A. H. Tatlow, Natal Province: Descriptive guide and official handbook (Durban: South African Railways Printing Works, 1911), 54. Public domain.

${ }^{159}$ Andrew MacDonald, "In the pink of health or the yellow of condition? Chinese workers, colonial medicine and the journey to South Africa, 1904-1907," Journal of Chinese Overseas, 4 (2008), 23-50.
} 
forced labour for the waterfront. ${ }^{160}$ Four years after the peace, the Bambatha Rebellion driven by Zulu peasants long disenchanted with colonial taxes and the broken promises of liberation during the recent War-produced several thousand insurgents in the Mpanza valley. Magistrates sent two thousand to the Point to serve sentences in Jacobs Camp, Bamboo Square's barracks (deemed a prison), and the Point Convict station nearby. ${ }^{161}$ Designed like the 'portable prisons' in use elsewhere on the colony's roads, the rebels themselves built this extensive building from wood, iron and recycled harbour material. From here, convicts dispersed daily to build the embankments then swallowing up the Congella swamps, between 1906-8.

The upswing in migration in the 1890s had alerted settler authorities to the reality that the colony lacked mechanisms to regulate seaborne migrants who were neither contract labourers nor convicts. Until then independent migrants faced no legal obstacle to landing, even if naturalisation and full property rights required an expensive application and the Lieutenant Governor's personal approval. ${ }^{162}$ In 1896 , protest by white workingclass artisans against free Indian immigration led to the Immigration Restriction Act (IRA); indeed the Point itself became a major epicentre for demonstrations. ${ }^{163}$ The final text of the 1897 Act targeted those 'unable to write in a European language,' a constitutional subterfuge to bypass Imperial restrictions on racial laws. It further denied landing to 'all idiots, insane persons, paupers, or persons likely to become a public charge, persons suffering from a loathsome or dangerous contagious disease, persons who have been convicted of a felony or other infamous crime or misdemeanour involving moral turpitude.' To this, law makers added a few exemptions, for prior residents, relatives, and compassionate cases. To enforce the new act, the government created an Immigration Restriction Department (IRD), with offices close to the main wharf at the Point. Harry Smith and Godfrey Dick, two English-born segregationists with the Harbour Department, took the helm and dealt with all aspects of immigration at the Point. Within a decade, they had created a tower of correspondence fourteen metres high. Asian travellers endured the thrust of this offensive, but Smith and Dick did not stop there.

\footnotetext{
${ }^{160}$ Swanepoel and Peté, "Punishment," 170-1.

161 Ibid., 190-3.

162 Cadiz (ed.), Ordinances, Ord. 6/1849, Law 4/1874.

${ }^{163}$ I cover this in more detail in my MA dissertation: Andrew MacDonald, "Strangers in a strange land: Undesirable and border-controls in colonial Durban, 1897-1910” (MA Diss., University of KwaZulu-Natal, 2007), 52-66, 165-8.
} 
Immigrant processing at the wharf became key. A team of officials and interpreters boarded steamers on arrival and set up an examination desk at the gangway. ${ }^{164}$ The officers served the IRA and Port Regulations on the Master, who raised an 'I flag' to signal examinations had commenced. Boarding teams then set a twenty-four-hour watch on the ship. The guards varied their positions, allowed nobody to board, and paid special attention to the ships' blindside. They required everybody, apart from 'Prominent Colonists' and 'Persons of Note,' to present themselves for identification and approval to disembark. The gangway officer laid out papers for signing: Educational Test Certificates, Prohibition Orders, Visiting Passes (for temporary landing permission) and Inward Passes (for black South Africans). As the investigations proceeded, the officer drew up a Borgesian assortment of lists. These detailed the number and nationalities of: Passengers Examined, Prohibited Persons, Crew, Extra-hands, Passage Workers, Natal Passengers, In-Transit Passengers, Natives, Holders of Domicile Certificates, and Holders of Mozambique Outward Passes. At the end of the survey, he prepared further lists for Deserters, Stowaways, and Holders of Confiscated (i.e., fraudulent) Certificates. He then summarised the information for the shipping index, wrote up accounts for guard payments, filled in charge sheets for lawbreakers, prepared telegraphic advice for Cape or Mozambican ports, and concluded the task by explaining anomalies in an office diary. Only then were IRD staff in a position to prepare the vessels' clearance papers and to stand down the watch carefully a few moments before it raised anchor for departure.

What of those not approved for disembarkation? The IRA ensured ships in the lagoon were the first line of defence. The steamships were liable for confining 'Prohibited Immigrants. ${ }^{165}$ This meant relegating a passenger or crewman to a locked space aboard so that the great symbols of global mobility became, in fact, floating prisons. Masters either arranged their own guard or paid the wages of Water Rats to do so. When crewmen met the minimum requirements of the Act and wished to stay in the colony, the Master had to find a substitute. When escapes occurred, masters became vulnerable to a $£ 100$ fine per deserter. The department could withhold a ship's clearance until the fine's settlement. The IRD compelled shipping companies to take responsibility for guarding, and to deport prohibited immigrants from their ships, if discovered. Protests from the lines at the

\footnotetext{
${ }^{164}$ NAB/Immigration Restriction Department (IRD) 46/1286 Notes and Standing Orders for the Guidance of Water Police, 1905

${ }^{165}$ Section 8 of the IRA lays out the obligations. See also NAB/IRD 1/1/1897 Suggestions re: carrying out the Act, 22 May 1897.
} 
severity of these impositions, and shippers' doubts of their legality, led the IRD to explore several further measures. ${ }^{166}$

The IRD lobbied the Water Police to recruit more ship guards; their roll call went from 30-odd to over 60 in $1905 .{ }^{167}$ It then reorganised the arrangements further by employing permanent, professionalised 'Boarding Officers' under the direct authority of Smith and Dick. ${ }^{168}$ In 1906, Smith purchased the Liitto, a sugar baron's houseboat (a 150foot Finnish-built coaster damaged in a collision in Port Elizabeth in 1901), for use as a 'Detention Hulk.' Close to a thousand guests stayed on it during its first three years of operation. ${ }^{169}$ But it was an old craft under an unreliable caretaker. By 1910, even the port officials regarded its rotting woods, worm infestations, and malodorous leakages an embarrassment (the Port Health office called it 'altogether filthy, and sadly out of repair... unfit for the accommodation of human beings.' $)^{170}$ Press coverage and official censure were expensive to the IRD's repute. Thereafter, the IRD searched for more suitable places of confinement. Sometimes they adapted the Health Department's quarantine building on Salisbury Island. At other times, the IRD used general cells in town, and at Water Police 'sub-stations' erected at Congella and the foot of Bluff; its airy design lightened the oppressive summer heat but invited the stench of decomposing carcasses from the whalers next door. ${ }^{171}$

During the 1910s, once unfamiliar words turned into common currency: Prohibited, Undesirable, Stowaway, Detention, Restriction. New kinds of action (and inaction) emerged: waiting, queuing, interviewing, dictating, writing, stamping, filing, and reporting. But we should not take the IRD's instructions at face value. For migrants, there were always options: posing, dissimulating, hoodwinking, hiding, climbing, jumping, swimming, scurrying. Confidential correspondence by Smith and Dick between 1898 and 1912 offers a shadow commentary on the published procedures. Smith complained soon after his appointment - one can sense the stiff lip - of 'no little difficulty' with arriving ships. ${ }^{172}$ It had taken only a few weeks after the IRD opened its doors in 1897 to record a deserter: an 'Arab' whom police subsequently found on Point Road. He was one of 120

\footnotetext{
${ }^{166}$ NAB/IRD 12/522/1902 Shipping Agents to Colonial Secretary, 29 July 1902; NAB/IRD 18/587/1903 Shipping Agents to Colonial Secretary, 15 June 1903.

${ }^{167}$ NAB/IRD 50/417/1904 Smith to Colonial Secretary, 6 Apr. 1905-19, Apr. 1906

${ }^{168}$ Ibid.

${ }^{169} \mathrm{NAB} / \mathrm{IRD} 62 / 345 / 1905$ Correspondence relating to the purchase of a Detention Hulk, 1905-11.

${ }^{170} \mathrm{NAB} / \mathrm{IRD} 68 / 624 / 1907$ Report of the Port Health Officer, undated, 1907.

${ }^{171}$ South African Archives Bureau, Pretoria (SAB)/Public Works Department (PWD) 2083/7367 Memorandum on Durban Immigration Detention Station, 1915-1924.

172 NAB/AR-IRD 1900, 3.
} 
arrested that year under the IRA. ${ }^{173}$ By 1901 Smith reported that his duties at the dock were 'at once anxious, harassing, and exacting to the highest degree and arising from the dark ways [of people] ... the work is full of incident. ${ }^{\prime 17}$ By 1905 he felt 'we might as well be without an Act,' so multifarious were the difficulties associated with policing the boats. ${ }^{175}$ In 1911, he took long leave, admitting 'the strain of an almost unbroken decade' as gatekeeper. ${ }^{176}$

Busy he had been. Between 1898 and 1910 Smith had investigated nearly a thousand cases of escape, many involving several individuals. ${ }^{177}$ There were probably more. Impatient masters did not always press charges for the delay it entailed; the Water Police tried to warn and deescalate rather than arrest. ${ }^{178}$ Officers were sometimes collaborators, and even the honest filed careless reports. In some seasons, vessels lost multiple travellers. The worst case was the SS Somali. Having arrived from the East African coast, the Water Police saw - or did not see - thirteen escapes on a single summer night in $1906 .{ }^{179}$

There were many ways ashore. ${ }^{180}$ Officers accepted bribes or capitulated before pettifoggers. Smith told of a 'spirit of quiet hostility' between his Immigration Department and Water Rats; he fumed over the 'gross negligence,' 'grave carelessness,' and 'serious dereliction' of 'men employed by the hour [and] who owe allegiance elsewhere.' ${ }^{181}$ Smith wrote of the 'confusing traffic' of the wharves, what some passengers at Durban called 'the fascination frantic,' that disguised clandestine activity (see fig. 11). ${ }^{182}$ Smith pointed out what he called 'poachers on the bay' among the seventy ferry craft for hire, whom he accused of abetting escapes by hovering on the blindside of becalmed ships. ${ }^{183}$ In 1917 a retired Water Rat looked backed on the opening decade of the century and described 'all sorts of tricks... [immigrants] jumped overboard, climbed down ropes and swam to the

\footnotetext{
${ }^{173}$ NAB/IRD 1/48/1897 Smith to Colonial Secretary, 14 Sep. 1897.

${ }^{174}$ NAB/ARIRD, 1902, 1.

175 NAB/IRD 42/857/1905 Correspondence relating to the SS Somali, 19 Aug. - 3 Oct. 1905.

${ }^{176} \mathrm{NAB} / \mathrm{IRD}$ 92/1904/1911 Smith to Secretary of the Interior, 16 Oct. 1911.

177 NAB/IRD 10/558/1902 Returns of escapes, 1898-1906.

178 “AR-CCP," NBB 1897, F-57. Borough police, a "zealous [and] formidable competitor" to the Water Police, also made arrests on the wharves but surviving statistics do not distinguish how many nor for what offence.

${ }^{179}$ NAB/IRD 42/857/1905 Correspondence relating to the SS Somali, 19 Aug. - 3 Oct. 1905.

${ }^{180}$ Many examples are detailed and fully cited in: MacDonald, "Strangers," 172-86.

${ }^{181}$ Ibid.

182 NAB/IRD 22/975/1903 Dick [quoting Smith] to Colonial Secretary, 22 Oct. 1903.

${ }^{183}$ For an example, see: NAB/IRD 12/870/1902 Smith to Water-Police, Oct. 1902. For poachers in general, see: NAB/IRD 391/1903 Harry Smith to Colonial Secretary and Attorney-General, 27 May 1903. For hire craft, see: "AR-CCP for 1897” $N B B, 1897$, F-59.
} 
landing steps. [It] was a continual battle of wits.' ${ }^{184}$ The ex-Water Rat recalled mates, masters and sometimes guards took part in the lively tobacco and alcohol trade.

The Point developed disorderly connotations, as letters in the city's bourgeois dailies bemoaned its 'pestilential ruffianism. ${ }^{185}$ Police thought there were at least three hundred 'desperate characters' smuggling liquor and running gambling dens around the lagoon. ${ }^{186}$ Smith saw 'nefarious trades' on his daily walks from his home at the Point. ${ }^{187}$ I have written elsewhere of the counterfeiters and forgers embedded in South Africa's early immigration regime, making and selling the full range of certificates on offer at the gangways. At the Point, the agents of Akoob, Osman \& Edwards (a Gujarati-English partnership) and Khan \& Donnelly (a Muslim-Catholic syndicate) touted for business after

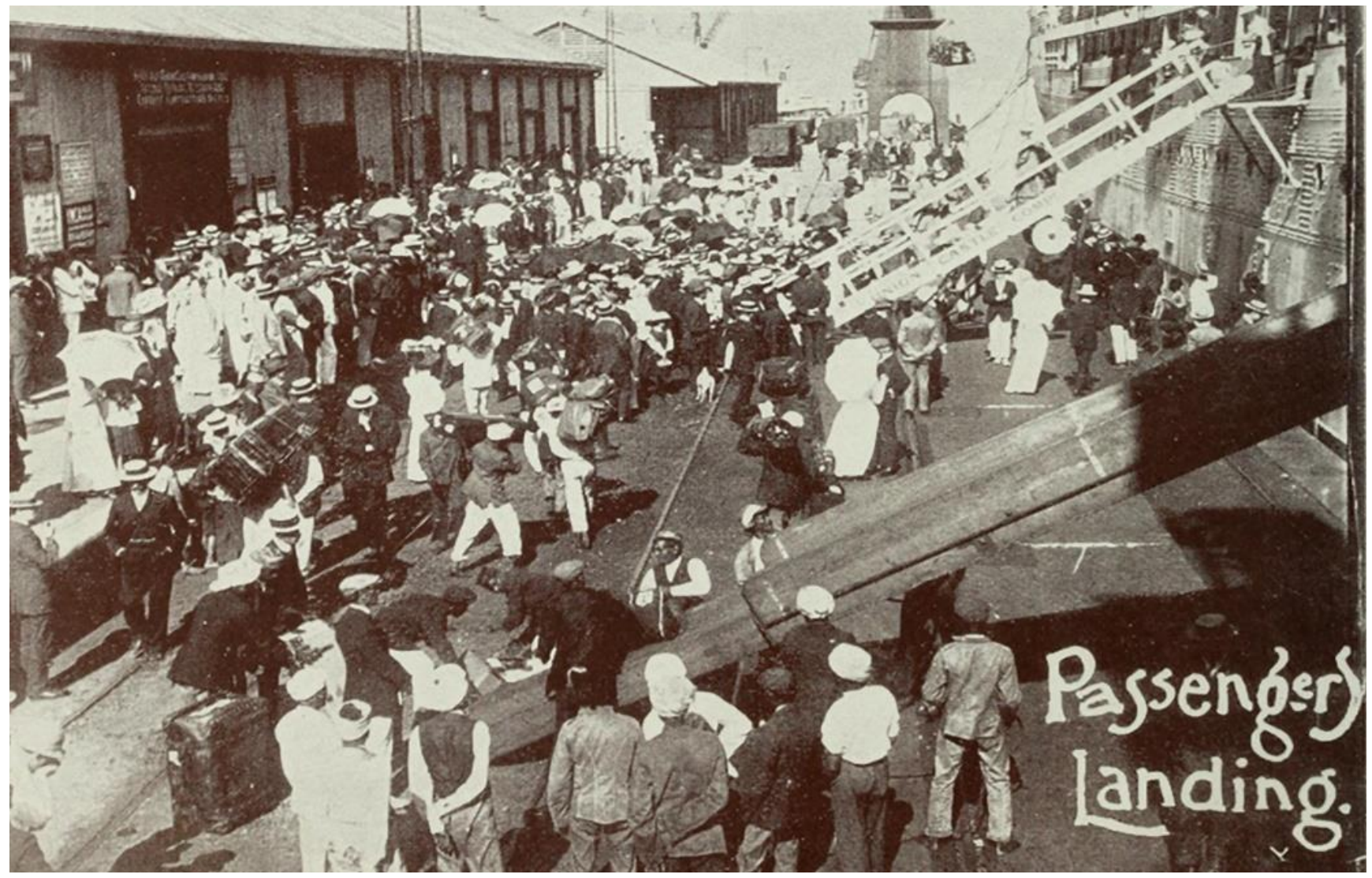

Fig. 11. Main Wharf, Shed E, c. $1910 .^{188}$

\footnotetext{
184 "Water police," Nongqai (Apr. 1917), 210-2.

${ }^{185}$ The Mercury, "Wanted, more police supervision," 6 Oct. 1897.

${ }^{186}$ DBP/MPR, Jan. 1901.

${ }^{187}$ NAB/IRD 391/1903 Smith to Col. Sec., 27 May 1903.

188 Tatlow, Natal, 36.
} 
1900. ${ }^{189}$ Ricksha-pullers, meanwhile, kept an illicit sex economy alive by touting at the Point for brothels closer to the Berea. ${ }^{190}$ At the same time, the docks developed into a space of revolt. Crews and soldiers sometimes led violent micro-mutinies against the brutal discipline of the ship or confinement on it. ${ }^{191}$ The image of incarceration and of travellers sent 'pillar to post' grew frequent in the pages of Gandhi's Indian Opinion. ${ }^{192}$ African dockworkers protested wages and arrests, the maritime variants of the South Africa's 'total institutions,' and struck or deserted. ${ }^{193}$ The fishermen of Bamboo Square and Salisbury Island partly re-established their communities soon after demolition, frustrating inspectors. ${ }^{194}$ They organised an informal fisherman's union, to fight ongoing struggles against authorities through multiple attempts at forced removal over the twentieth century. Smuggling and pilferage echoed in both African and settler memories of the port's informal economy well into the twentieth century. ${ }^{195}$

The official view of the harbour as an unruly space fuelled authorities' activism after 1910. Immigration scholars have shown how the Union immigration regime redoubled their efforts, but the fundamental trajectories, the path dependencies, were well in place. ${ }^{196}$ Port officials tinkered with the most efficient ways to isolate passengers and crew from the shore. They simplified and standardised the gangway examinations with a new Landing Declaration in 1913 and tallied these with more sophisticated manifests. Union immigration officers made educational and means tests harder to pass, and more openly discriminated on racial grounds. Reforms within the Water Police made it more difficult for unauthorised migrants to evade inspection at the waterfront. In 1922, the IRD converted the Indian immigration barracks into the 'Durban Detention Depot,' capable of holding several hundred Prohibited Immigrants at a time. ${ }^{197}$

\footnotetext{
${ }^{189}$ NAB/IRD 7/58/1902 Anonymous to Smith. 29 Jan. 1902; The Mercury, “Alleged Forgeries,” 31 Aug. 1910.

${ }^{190}$ Ros Posel, “'Continental women' and Durban's 'social evil,' 1899-1905,” JNZH, 12, 1 (1989), 1-13.

191 Jonathan Hyslop, "Oceanic mobility and settler-colonial power: Policing the global maritime labour force in Durban harbour c. 1890-1910," Journal of Transport History, 36, 2 (2015), 248-67.

192 For example: Indian Opinion, "Death of another passive resister," 22 Oct. 1910.

${ }^{193}$ Hemson, “Class consciousness," 32, 66-71.

194 Govender and Chetty, Legends, 106-12.

${ }^{195}$ Lawrence Green, Harbours of Memory (Cape Town: Timmins, 1982); Ralph Callebert, "Cleaning the wharves: Pilferage, bribery, and social connections on the Durban docks in the 1950s," Canadian Journal of African Studies, 46, 1 (2012), 23-38.

196 Jonathan Klaaren. "Migrating to citizenship: Mobility, law and nationality in South Africa, 1897-1937” (Unpublished Ph.D. diss., Yale University, 2004), esp. Ch. 4.

197 SAB/PWD 2083/7367 Papers re: Durban Immigration Detention Station, 1915-1924.
} 


\section{CONCLUSION}

The processes described above were effectively complete by about 1910 (see appended maps). But city planners had one last move to play. Scholars of industrialisation have shown how nineteenth-century romantics, their towns enclosed and despoiled, turned away from mountains to the oceans - in their sublime, wild immensity - for refuge, redemption and stimulation. ${ }^{198}$ As the salty brine took on therapeutic, even cultic, meanings, so the sea and its beaches offered opportunities for the reconstitution of body and family. By the later nineteenth century, the seaside came to be associated with masculine heroism and virility, with feminine fertility (soon sexuality) and childhood innocence. As Gillis shows, the esteem in which large parts of Atlantic society held the ocean explains the striking pervasion of nautical artefacts in nineteenth-century metropolitan (and colonial) culture: fascinations with toy boats, sailor suits, aquariums, shell collections, seascape painting and voyage-books (matched by morbid ruminations on shark attacks and shipwrecks). New practices such as bathing, contemplative watergazing and beach-strolling or picnicking - unthinkable in prior centuries - came into being. Around the Atlantic especially, new kinds of waterfronts emerged, with bathing enclosures (sometimes 'machines'), piers, promenades, cabins and decorous hotels, that simultaneously brought the sea closer while eradicating its less salubrious smells, sights and sensations. Urban developers emptied motley urban shores and replaced them with open horizons, recreation phantasia and vacationers.

Durban became a striking Indian Ocean exemplar of this shift. As authorities erased the long history of the lagoon, Edwardian beautifiers - a symphony of municipal architects, railways publicists and hoteliers - reorientated the 'front' of the town to Back Beach. After five years of planning, a settler playground, renamed 'Ocean Beach,' took shape in the 1910s. ${ }^{199}$ Inspired in part by the City Beautiful movements in Chicago, its designers transformed the dunes over which Flatta had once reigned with a manicured promenade, a 'shark-proof' bathing ring and paddling ponds. To these, developers added a Beach Pavilion and a 'fairyland' that included a water slide, a 'switchback' rollercoaster, a model dairy, and a snake park, all topped by medieval turrets.

Despite frequent damage to Ocean Beach by high seas, reformers pressed ahead in the 1920s and 30s. They extended roads to create the modern Marine Parade from

\footnotetext{
${ }^{198}$ Seminal is: Alain Corbin, The Lure of the Sea: The discovery of the seaside in the western world, trans. Jocelyn Phelps (Berkeley: University of California Press, 1994). See also: Gillis, Human Shore, Ch. 5.

${ }^{199}$ Michelle Jacobs and Brian Kearney, The Berea Style: The architecture of William Murray-Jones and Arthur Ritchie McKinley (Durban: Durban Heritage Trust, 2018).
} 
Addington to the Umgeni mouth (renamed 'Blue Lagoon') and decorated them with public swimming pools, colonnaded changing rooms, bowling greens and a civic amphitheatre, each for Europeans. These were the preludes to Apartheid's 'Whites Only' beaches from the 1960s and then post-Apartheid's multi-racial Golden Mile, 'where the fun never sets' in the phrasing of tourist paraphernalia. The transformation of Back Beach now embraces the Point itself, the site of luxury apartments, themed water parks and cruise ship facilities, even if underworlds and scandal continue to mock, and even constitute, urban development here in the twenty-first century. ${ }^{200}$

Over the long twentieth century, the ancient lagoon itself became ever denser with breakwaters, piers, and concrete wharfs, today stretching twenty kilometres and able to accommodate over fifty modern ships. ${ }^{201}$ Landward are coal bunkers, automated cranes and container terminals, linked to marshalling yards and 300 kilometres of shoreline railways. Ironically, construction in the 1960s destroyed the complex of neo-classical waterfront buildings that had earlier secured the lagoon for colonial capital. On the water are floating repair docks, dredger plants and a fleet of tugs, survey vessels and rescue craft. The port embraces too the air above, with helicopters (ferrying local pilots to and from the offshore anchorage) and arcs of light from navigational towers. The works now cover 2,000 hectares and employ fifty thousand people. A mix of state and private enterprise annually handles 120 million tonnes of cargo (or 2.8 million containers), under watchful security. ${ }^{202}$ This has made it southern and eastern Africa's largest port, and a major transhipment point for the south-west Indian Ocean. ${ }^{203}$ But the skeleton enrobed in a black shawl had a more interesting story to tell, if we care to listen.

\footnotetext{
${ }^{200}$ Ashwin Desai and Patrick Bond, "Speculators and scoundrels in South Africa's secondary circuit of capital: A turbulent investment climate at Durban's Point Waterfront," Socialism and Democracy, 33, 2 (2019), 108-41.

201 The later twentieth-century history of the port may be traced through: Lumby, "The South African economy," 21-34; Lumby, "The development of the port," 105-13.

2022019 statistics. See: https://africaports.co.za/durban/ [Accessed: 27 Jan. 2021].
} 


\section{APPENDIX \#1: MaP OF DURban's Lagoon, DraWn by the AUThOR}

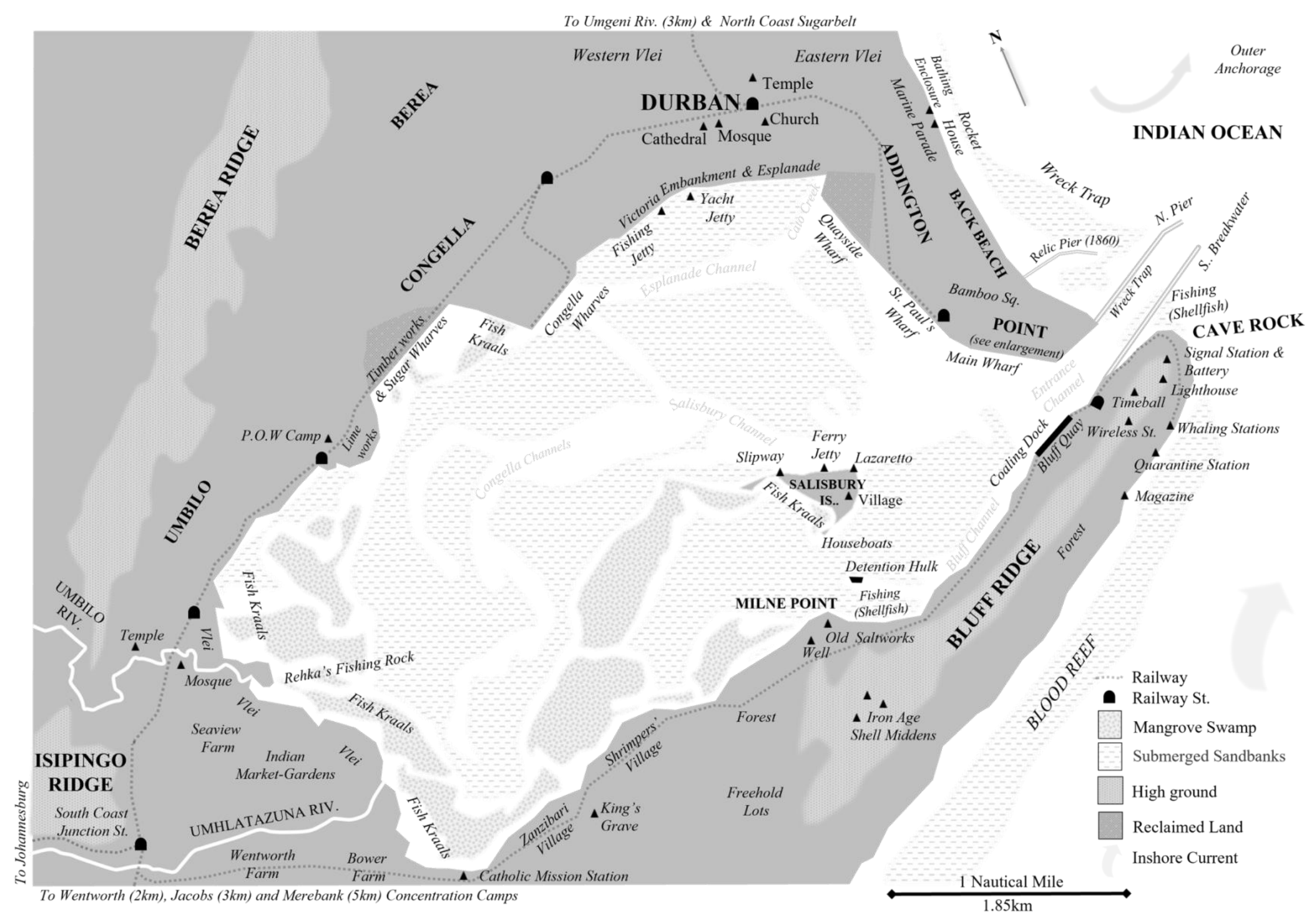




\section{Appendix \#2: Enlarged Map of The Point Area, Drawn by the Author}

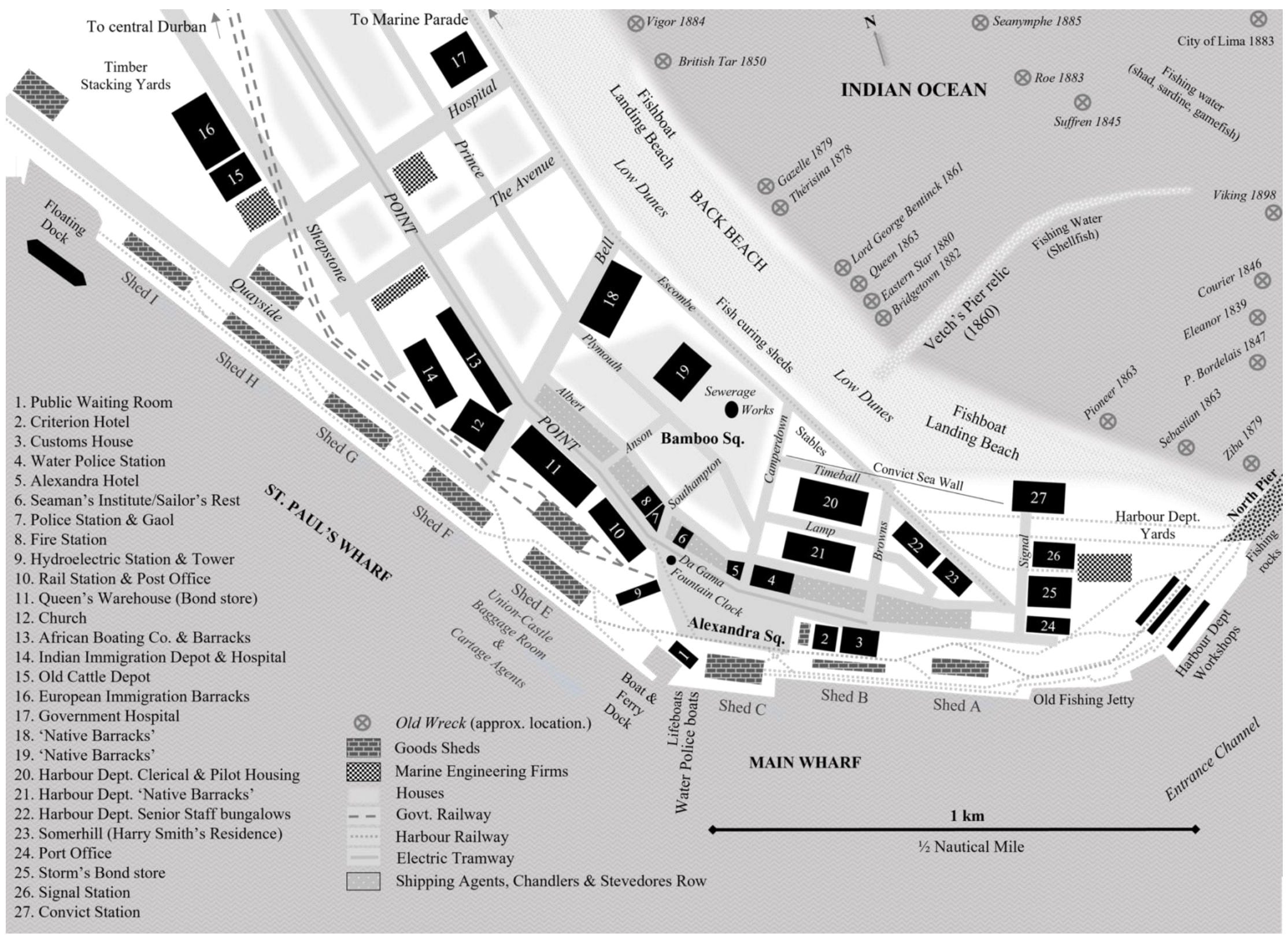

